Additional services for Early Music History:

Email alerts: $\underline{\text { Click here }}$

Subscriptions: $\underline{\text { Click here }}$

Commercial reprints: Click here

Terms of use : $\underline{\text { Click here }}$

\title{
GIOSEFFO ZARLINO AND THE MISERERE TRADITION: A FERRARESE CONNECTION?
}

Katelijne Schiltz

Early Music History / Volume 27 / October 2008, pp 181 - 216

DOI: 10.1017/S0261127908000314, Published online: 11 August 2008

Link to this article: http://journals.cambridge.org/abstract_S0261127908000314

How to cite this article:

Katelijne Schiltz (2008). GIOSEFFO ZARLINO AND THE MISERERE TRADITION: A FERRARESE CONNECTION?. Early Music History, 27, pp 181-216 doi:10.1017/S0261127908000314

Request Permissions : $\underline{\text { Click here }}$ 


\section{GIOSEFFO ZARLINO AND THE MISERERE TRADITION: A FERRARESE GONNEGTION?}

Through Patrick Macey's extensive research on Josquin des Prez's Miserere mei Deus, the historical context of this monumental motet, especially its connection with the Savonarolan reform movement and its repercussions at the Este court of Ferrara, has received major attention. ${ }^{1}$ Above all, Macey has shown how this piece generated a whole cluster of compositions throughout the sixteenth century that bear musical, structural and/or textual references to Josquin's work. ${ }^{2}$ One of the main elements of this intertextual web includes the use of Josquin's soggetto ostinato - either literally or with slight variations - by composers such as Adrian Willaert, Cipriano de Rore and Nicola Vicentino, who were all connected with the Este court at a certain point in their careers. ${ }^{3}$ Macey's discoveries have brought to light a highly intriguing reception history, to which other scholars have also contributed. ${ }^{4}$ In the present essay, I wish to add

Portions of this text were presented during research seminars at the Universities of Utrecht and Cork, and at the Medieval and Renaissance Music Conference in Vienna (August 2007). A shorter version of this article appeared under the title 'Self-Citation and Self-Promotion: Zarlino and the Miserere Tradition', in M. Delaere and P. Bergé (eds.), 'Recevez ce mien petit labeur': Studies on Renaissance Music in Honour of Ignace Bossuyt (Leuven, 2008), pp. 211-25. I am grateful to Bonnie J. Blackburn, Camilla Cavicchi, Leofranc HolfordStrevens, Wolfgang Horn, Cristle Collins Judd, Frans Wiering and the anonymous readers for reading an earlier draft of this article and for their helpful comments.

1 See P. Macey, 'Savonarola and the Sixteenth-Century Motet', Fournal of the American Musicological Society, 36 (1983), pp. 422-52, at 448-52; id., 'Josquin's Miserere mei Deus: Context, Structure and Influence' (Ph.D. diss., University of California, Berkeley, 1985); id., Bonfire Songs: Savonarola's Musical Legacy (Oxford, 1998), esp. pp. 184-92; id., 'Josquin and Musical Rhetoric: Miserere mei, Deus and Other Motets', in R. Sherr (ed.), The Josquin Companion (Oxford, 2000), pp. 485-530, at 492-523.

2 Many of these pieces have been edited in Savonarolan Laude, Motets, and Anthems, ed. P. Macey (Recent Researches in the Music of the Renaissance, 116; Madison, 1999).

3 Macey, 'Josquin's Miserere mei Deus', p. 157: 'Josquin's soggetto established itself as a kind of musical topos during the sixteenth century.'

4 B. Bujić, 'Peccantem me quotidie: Gallus's Homage to Josquin?', in D. Cvetko and D. Pokorn (eds.), Facobus Gallus and his Time (Ljubljana, 1985), pp. 70-81; L. Finscher, 'aus sunderem Lust zu den überschönen worten: Zur Psalmkomposition bei Josquin Desprez und seinen Zeitgenossen', in H. Boockmann, L. Grenzmann, B. Moeller and M. Staehelin (eds.), Literatur, Musik und Kunst 


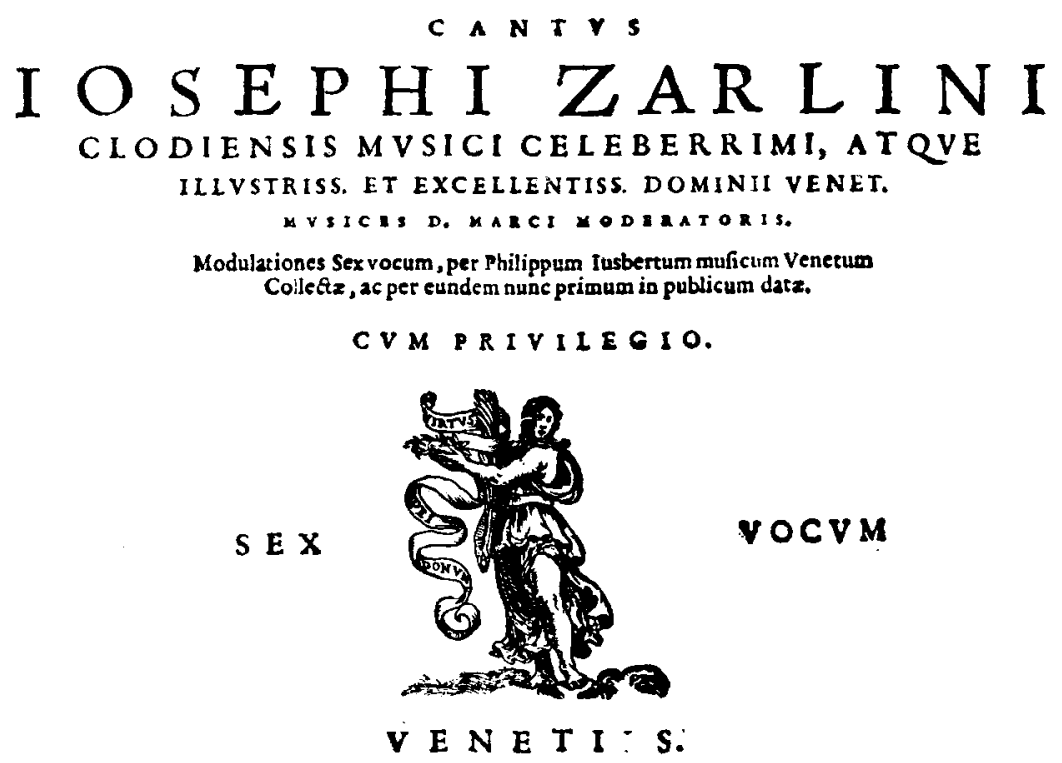

Figure 1 Gioseffo Zarlino, Modulationes sex vocum (Venice, 1566), title page. By permission of the Bayerische Staatsbibliothek München, Musikabteilung

yet another piece of evidence to the afterlife of this Miserere tradition. I will focus on two lesser-known motets by Gioseffo Zarlino, Miserere mei Deus and Misereris omnium, both of which were published in his collection Modulationes sex vocum (Venice, 1566) (see Figure 1). ${ }^{5}$ Not only did they inscribe themselves in the intertextual network that was initiated by Josquin, but also they can be linked to the Ferrarese court in general and to Duke Alfonso II in particular.

\section{MISERERE MEI DEUS AND MISERERIS OMNIUM IN THE \\ GONTEXT OF ZARLINO'S MODULATIONES SEX VOCUM}

Although Zarlino is mainly known for his theoretical writings, he also composed motets and a number of madrigals. ${ }^{6}$ His first book of

im Übergang vom Mittelalter zur Neuzeit: Bericht über Kolloquien der Kommission zur Erforschung der Kultur des Spätmittelalters 1989-1992 (Göttingen, 1995), pp. 246-61; P. Macey, 'Italian Connections for Lupus Hellinck and Claude Le Jeune', in E. Schreurs and B. Bouckaert (eds.), Giaches de Wert (1535-1596) and his Time: Migration of Musicians to and from the Low Countries (Yearbook of the Alamire Foundation, 3; Leuven and Peer, 1999), pp. 151-63.

5 For a modern edition of Misereris omnium, see G. Zarlino, Drei Motetten und ein geistliches Madrigal zu 4-6 Stimmen, ed. R. Flury (Das Chorwerk, 77; Wolfenbüttel, 1959), pp. 19-24.

6 For an overview of Zarlino's compositional oeuvre, see R. Flury, Gioseffo Zarlino als Komponist (Winterthur, 1962). 
motets, published in 1549 under the title Musici quinque vocum moduli, has received attention in musicological literature because of its careful text underlay, the modal labels that were attached to the individual pieces and its hidden eight-mode cycle based on the Song of Songs. ${ }^{7}$ In 1566, one year after Zarlino's appointment as chapel master of St Mark's in Venice (on 5 July 1565) and his election as a chaplain at the church of San Severo, the collection Modulationes sex vocum was printed. ${ }^{8}$ Unlike Zarlino's other publications, the volume lacks any of the hallmarks of 'luxurious' printing and judging by its format, scope and length - should rather be considered a workaday set of partbooks. ${ }^{9}$ Moreover, the Modulationes was not issued by one of the primary Venetian printing firms such as Scotto and Gardano, but by the house of Francesco Rampazetto. ${ }^{10}$ Unlike the earlier motet collection, the works of the Modulationes comprise primarily 'functional' liturgical items, such as antiphons, a sequence, a responsory, etc. The book consists of thirteen pieces (see Table 1), all of which (except for Exaudi Deus orationem - Scrutati sunt iniquitates) contain a canon for two or three voices. Some of the canonic inscriptions are relatively straightforward technical instructions, but others are conceived as enigmatic sentences. The book closes with a seven-part Pater noster - Ave Maria, which had already appeared in the collection of $1549 .{ }^{11}$

7 M. S. Lewis, 'Zarlino's Theories of Text Underlay as Illustrated in his Motet Book of 1549', Notes, 42 (1985), pp. 239-67 and C. C. Judd, 'A Newly Recovered Eight-Mode Motet Cycle from the 1540s: Zarlino's Song of Songs Motets', in A.-E. Ceulemans and B. J. Blackburn (eds.), Music Theory and Analysis 1450-1650: Proceedings of the International Conference Louvain-laNeuve, 23-25 September 1999 (Musicologica neolovaniensia, 9; Louvain-la-Neuve, 2001), pp. 229-70. See now also Gioseffo Zarlino, Motets from 1549 Part 1: Motets Based on the Song of Songs, ed. C. C. Judd (Recent Researches in the Music of the Renaissance, 145; Middleton, Wis., 2006) and id., Motets from 1549 Part 2: Selected Motets from Musici quinque vocum moduli (Venice 1549), ed. C. C. Judd (Recent Researches in the Music of the Renaissance, 149; Middleton, Wis., 2007).

8 The only complete set of partbooks is kept at the Bavarian State Library (shelfmark 4 Mus.pr. 172\#Beibd. 4).

9 See also C. C. Judd, Reading Renaissance Music Theory: Hearing with the Eyes (Cambridge, 2000), p. 249.

10 Between 1565 and 1568 Rampazetto used a printer's mark (showing Virtus, who helds a banderole with the text 'Virtus Dei donum' and a palm) that Plinio Pietrasanta had already used for some music publications in the 1550 s. This could mean that Pietrasanta acted as silent partner for Rampazetto's prints; see also C. I. Nielsen, 'Francesco Rampazetto, Venetian Printer, and a Catalogue of his Music Editions' (MA thesis, Tufts University, 1987).

11 In a paper given at the Medieval and Renaissance Music Conference (Vienna, August 2007), Cristle Collins Judd discussed the two versions of this motet: "How to Assign Note Values to Words": Gioseffo Zarlino's Pater noster - Ave Maria (1549 and 1566)'. 
Katelijne Schiltz

Table 1 Gioseffo Zarlino, Modulationes sex vocum: contents and tonal types

\begin{tabular}{|c|c|c|c|c|}
\hline No. & Text incipit & System & Clefs & Final \\
\hline 1. & Ascendo ad patrem meum & - & g2-c2-c2-c3-c3-f3 & G \\
\hline 2. & Litigabant Iudaei & b / - & c1-c2-c2-c3-c4-f4 & $\mathrm{F}$ \\
\hline 3. & Hodie Christus natus est & $b /-$ & $\mathrm{g} 2-\mathrm{c} 2-\mathrm{c} 2-\mathrm{c} 3-\mathrm{c} 4-\mathrm{f} 3$ & G \\
\hline 4. & $\begin{array}{l}\text { Exaudi Deus orationem meam } \\
\text { Scrutati sunt iniquitates }\end{array}$ & - & c1-c3-c3-c4-c4-f4 & $\mathrm{D}$ \\
\hline 5. & Virgo prudentissima & $b /-$ & c1-c2-c3-c3-c4-f4 & $\mathrm{D}$ \\
\hline 6. & $\begin{array}{l}\text { Miserere mei Deus } \\
\text { Misit Deus misericordiam } \\
\text { Foderunt ante faciem meam }\end{array}$ & $b /-$ & c2-c4-c4-f4-f4-f5 & $\mathrm{E}$ \\
\hline 7. & $\mathrm{O}$ quam gloriosum & $b /-$ & c1-c3-c4-f3-f3-f4 & $\mathrm{F}$ \\
\hline 8. & $\begin{array}{l}\text { In principio Deus } \\
\text { Quando praeparabat }\end{array}$ & $-/ \#$ & c1-c3-c3-c3-c4-f4 & G \\
\hline 9. & $\begin{array}{l}\text { Victimae paschali laudes } \\
\text { Dic nobis Maria }\end{array}$ & $b$ & $\mathrm{~g} 2-\mathrm{g} 2-\mathrm{c} 2-\mathrm{c} 3-\mathrm{c} 3-\mathrm{f} 3$ & G \\
\hline 10. & Misereris omnium & - & c2-c3-c3-f3-f4-f5 & $\mathrm{E}$ \\
\hline 11. & Sebastianus Dei cultor & - & c1-c3-c3-c3-c4-f4 & $\mathrm{D}$ \\
\hline 12. & $\begin{array}{l}\text { Salve regina } \\
\text { Eia ergo } \\
\text { Et Iesum benedictum }\end{array}$ & - & c1-c1-c3-c4-f3-f4 & $\mathrm{D}$ \\
\hline 13. & $\begin{array}{l}\text { Pater noster } \\
\text { Ave Maria }\end{array}$ & $b$ & c1-c2-c3-c3-c4-c4-f4 & G \\
\hline
\end{tabular}

Miserere mei Deus (no. 6) and Misereris omnium (no. 10) share a striking number of characteristics. First of all, both pieces have a common liturgical context, the beginning of Quadragesima: Misereris omnium is the Introit for the feast of Ash Wednesday, Miserere mei Deus the Gradual for the same day. ${ }^{12}$ Needless to say, Ash Wednesday marks the beginning of the season of Lent, a period of penance, reflection and fasting which prepares the faithful for Christ's Resurrection on Easter Sunday, through which one attains redemption. The text of the Introit is based on Wisdom of Solomon 11: 24 (Sed misereris omnium, quia omnia potes, et dissimulas peccata hominum propter paenitentiam) and 27 (Parcis autem omnibus, quoniam tua sunt, Domine, qui amas animas). The verses of this apocryphal biblical text are followed by the psalm verse 'Miserere mei Deus, miserere mei: quoniam in te confidit anima mea' (Ps. 56: 2).

${ }^{12}$ Cf. Graduale Triplex (Solesmes, 1979), pp. 62-3. 


\section{Gioseffo Zarlino and the Miserere Tradition}

Misereris omnium Domine, et nihil odisti eorum quae fecisti, dissimulans peccata hominum propter paenitentiam, et parcens illis, quia tu es Dominus Deus noster.

Miserere mei Deus, miserere mei: quoniam in te confidit anima mea.

Thou hast mercy upon all, O Lord, and hatest none of the things which thou hast made, overlooking the sins of men for the sake of repentance, and sparing them: because thou art the Lord our God.

Have mercy on me, O God, have mercy on me: for my soul trusteth in thee. ${ }^{13}$

Although the incipit of Zarlino's Miserere mei Deus suggests that it uses the same text as Josquin's motet (Ps. 50), his composition is based on another psalm (Ps. 56: 2-11), ${ }^{14}$ whose text he divides - just like Josquin - into three parts (Miserere mei Deus - Misit Deus misericordiam suam - Foderunt ante faciem meam) of sixty, sixty-three and sixty-four bars respectively. The fact that the same psalm is also the source for the Gradual (as well as the psalm verse of the Introit) - it is rare for these parts of the Proper of the Mass to be linked in this way - creates a strong connection between the two texts, which will have major consequences for Zarlino's settings (the beginning of each pars is marked in bold):

2. Miserere mei Deus, miserere mei: quoniam in te confidit anima mea et in umbra alarum tuarum sperabo donec transeat iniquitas.

3. Clamabo ad Deum altissimum, dum [recte Deum] qui benefecit mihi.

4. Misit de coelo et liberavit me, dedit in opprobrium circundantes me.

Misit Deus misericordiam suam et veritatem suam.

5. Et eripuit animam meam de medio catulorum leonum, dormivi conturbatus.

Filii hominum dentes eorum arma et sagittae, et lingua eorum gladius acutus.

6. Exaltare super coelos Deus et in omni terra gloria tua.

7. Laqueum paraverunt pedibus meis et incurvaverunt animam meam.

Foderunt ante faciem meam foveam, et inciderunt in eam.

8. Paratum cor meum Deus, cantabo et psalmum dicam,

9. Exurge gloria mea, Exurge psalterium et cithara, exurgam diluculo.

10. Confitebor tibi in populis Domine, et psalmum dicam tibi in gentibus.

11. Quoniam magnificata est usque ad coelos misericordia tua, et usque ad nubes veritas tua. ${ }^{15}$

Have mercy on me, O God, have mercy on me: for my soul trusteth in thee.

And in the shadow of thy wings will I hope, until iniquity pass away.

I will cry to God the most High; to God who hath done good to me.

He hath sent from heaven and delivered me: he hath made them a reproach that trod upon me.

God hath sent his mercy and his truth,

13 Translation quoted from <http://www.dailycatholic.org/issue/05Feb/feb9pom.htm> (Wisdom of Solomon 11: 24 and 27) and the Reims-Douay-Challoner translation of the Vulgate (Psalm 56: 2).

${ }_{14}$ Macey, 'Josquin's Miserere mei Deus', p. 175 mentions a similar case for Hubert Waelrant's Miserere mei, Domine, whose text is based on Matthew 15: 22-8.

15 Translation from the Reims-Douay-Challoner Bible. 


\section{Katelijne Schiltz}

And he hath delivered my soul from the midst of the young lions. I slept troubled. The sons of men, whose teeth are weapons, and their tongue a sharp sword. Be thou exalted, O God, above the heavens, and thy glory above all the earth. They prepared a snare for my feet; and they bowed down my soul.

They dug a pit before my face, and they are fallen into it.

My heart is ready, O God, my heart is ready: I will sing, and rehearse a psalm.

Arise, $\mathrm{O}$ my glory, arise psaltery and harp: I will arise early.

I will give praise to thee, O Lord, among the people: I will sing a psalm to thee among the nations.

For thy mercy is magnified even to the heavens: and thy truth unto the clouds. ${ }^{16}$

Nevertheless, as we will see, this identical textual opening serves as a kind of aural signal, and it inspired Zarlino to make a clear musical reference to Josquin's masterpiece.

Apart from their common liturgical origin, both Misereris omnium and Miserere mei Deus are written in the fourth mode, with final $\mathrm{E}$ and low clefs. ${ }^{17}$ According to Zarlino's Istitutioni harmoniche (Venice, 1558), this mode was indeed 'said by musical practitioners to be marvelously suited to lamentful words or subjects that contain sadness or supplicant lamentation'. ${ }^{18}$ The two motets also use the same cantus firmus - albeit with some melodic differences (see Figures 2 and 3) - on the text $\mathcal{N}$ e reminiscaris Domine, which is treated canonically (see below). The text of $\mathcal{N e}$ reminiscaris Domine is taken from the apocryphal biblical book Tobit 3: 3. Like Miserere mei Deus and Misereris omnium, this antiphon can also be linked with Ash Wednesday. Ne reminiscaris Domine was usually recited before and after the seven Penitential Psalms, ${ }^{19}$ which were sung during the ceremony of the ashes on Ash Wednesday, when Christians who had committed grave sins performed public penance. On Ash Wednesday, the bishop blessed the hair shirts which they were to wear during the forty days of penance, and sprinkled over them ashes made from the palms from the previous year. Then,

16 Zarlino did not set the last verse of the psalm, which duplicates verse 6 .

17 Miserere mei Deus: c2-c4-c4-f4-f4-f5; Misereris omnium: c2-c3-c3-f3-f4-f5. It is worth noting that these are the only pieces in the Modulationes with final E. In Modena, Biblioteca Estense, MS C.314 (on which see below) both Misereris omnium and Miserere mei Deus are notated a fourth higher (c1-c2-c3-c3-c4-f4 and c1-c2-c3-c4-c4-f4 respectively), which produces a much brighter sonority than in the 1566 edition.

18 Zarlino, Le istitutioni harmoniche (Venice, 1558), p. 324: 'Questo medesimamente, secondo la loro opinione, si accommoda maravigliosamente a parole, o materie lamentevoli, che contengono tristezza, overo lamentatione supplichevole' (Bk. IV, ch. 21). Translation quoted from V. Cohen and C. V. Palisca, Gioseffo Zarlino: On the Modes. Part Four of "Le Istitutioni harmoniche", 1558 (New Haven and London, 1983), p. 64.

19 See Liber Usualis (Paris, 1950), p. 1840. 


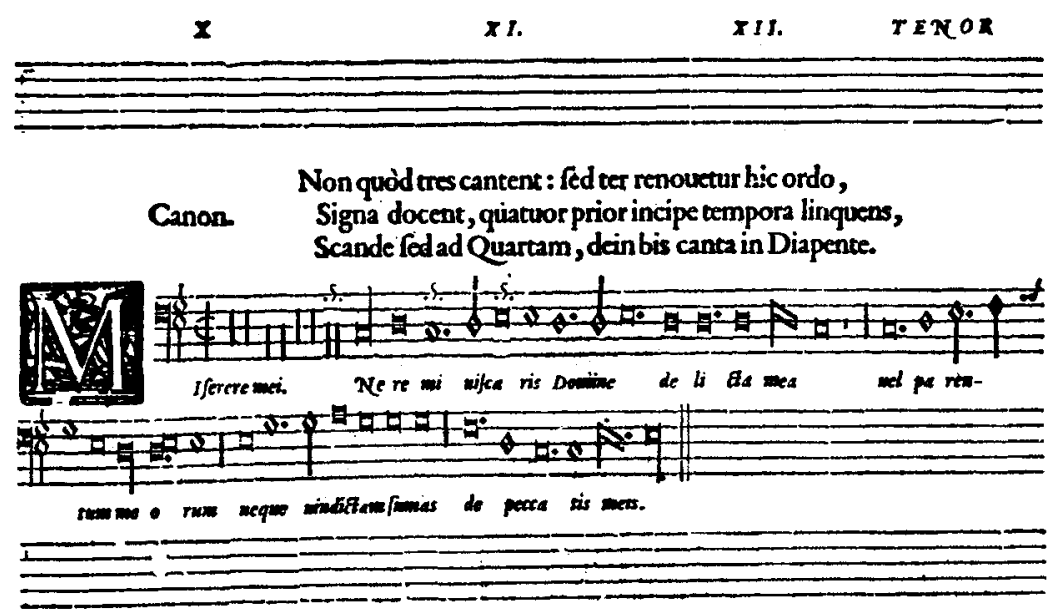

SECVNDA ET TEKTIA PARS CANITVR VT PRIMA.

Figure 2 Gioseffo Zarlino, Miserere mei: canon on the words Ne reminiscaris Domine.

By permission of the Bayerische Staatsbibliothek München, Musikabteilung

while the faithful recited the seven Penitential Psalms, the penitents were turned out of the church because of their sins - just as Adam, the first man, was turned out of Paradise because of his disobedience. ${ }^{20}$

In Miserere mei Deus, Zarlino added the instruction 'Not that three should sing, but this order shall be renewed three times, do the signs teach you: you start by first dropping four pauses, but ascend a fourth. Then sing twice at the fifth' to describe the changing canonic relationship between Tenor and Sextus in the composition's three partes (see Figure 2 and Example 1). ${ }^{21}$ The Tenor always starts on $c^{\prime}$ at bar 17 , but whereas in the prima pars the Sextus is the dux (bar 13), which is imitated a fourth below (see Example 1a), in the two other parts this voice is the comes that duplicates the Tenor at the upper fifth after three (bar 20) and

20 The link between Ne reminiscaris Domine and the seven Penitential Psalms is explicitly made by Loyset Piéton. Around 1532 Jacques Moderne printed the composer's set of psalms, which together with the appended antiphon $\mathcal{N e}$ reminiscaris Domine - form a modally ordered cycle. Piéton also uses a soggetto ostinato for Miserere mei Deus, based on a version of the fourth psalm tone, and places it in the superius. See also Macey, Bonfire Songs, p. 213, n. 47.

21 'Non quòd tres cantent: sed ter renovetur hic ordo, / Signa docent, quatuor prior incipe tempora linquens, / Scande sed ad Quartam, dein bis canta in Diapente'. 
Katelijne Schiltz

$X Y I I$.

TINOA

\section{Canon. Clauibus ingreditor,catera cuncta patent}

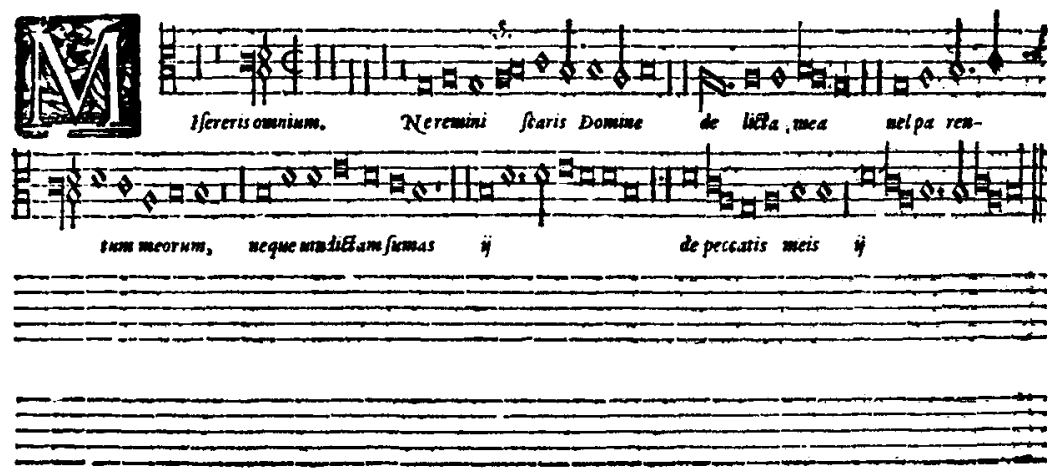

Figure 3 Gioseffo Zarlino, Misereris omnium: canon on the words Ne reminiscaris Domine. By permission of the Bayerische Staatsbibliothek München, Musikabteilung
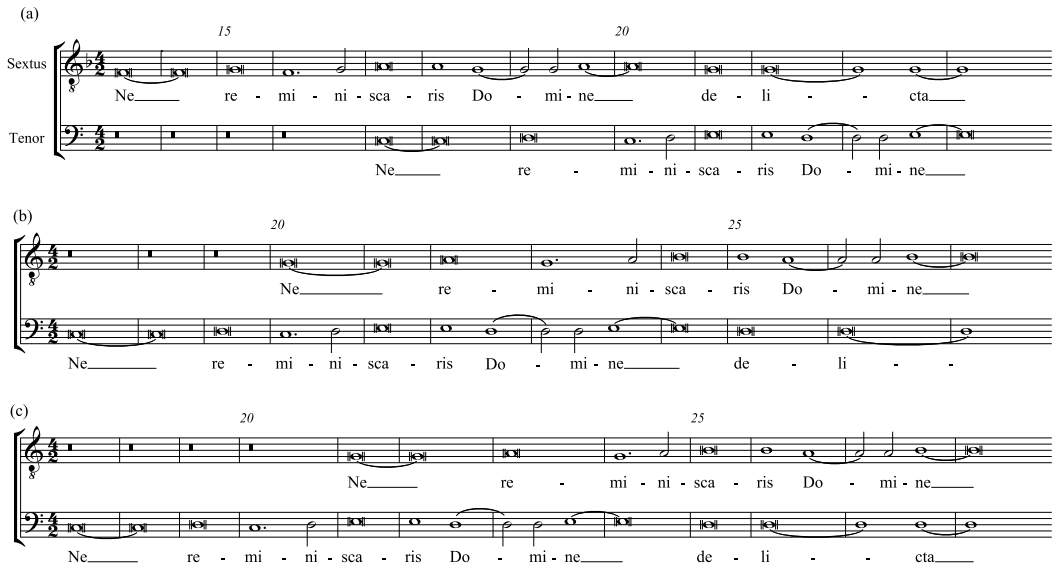

Example 1 Gioseffo Zarlino, Miserere mei Deus: beginning of the two-part canon: (a) prima pars (bb. 13-24); (b) secunda pars (bb. 17-27); (c) tertia pars (bb. 17-28)

four breves (bar 21) respectively (see Examples $1 \mathrm{~b}$ and 1c). Zarlino thus conceived the canonic melody in such a way that it can be combined with (a transposed version of) itself in three different ways. Moreover, the exchange of $d u x$ and comes between 


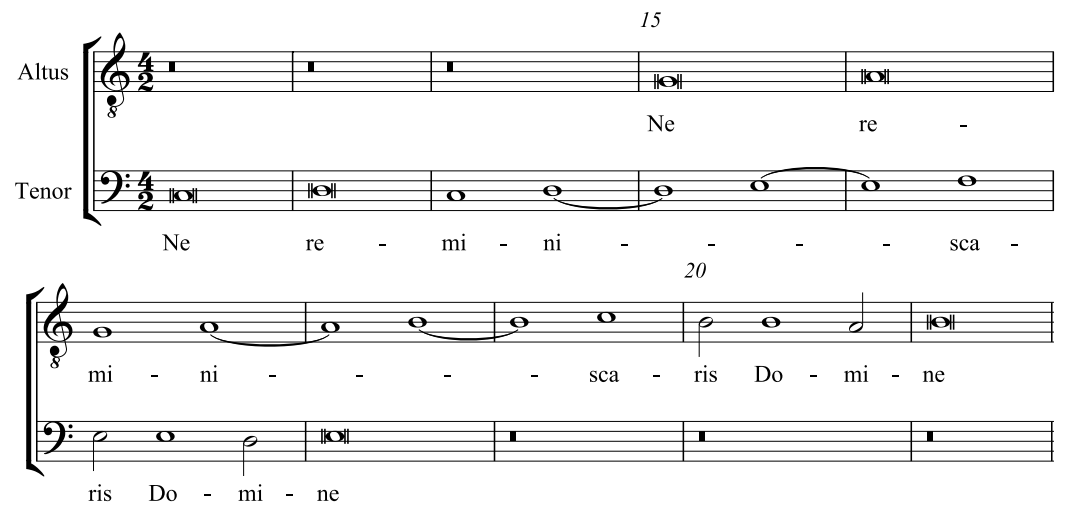

Example 2 Gioseffo Zarlino, Misereris omnium: two-part canon (beginning)

the partes is a technique he explicitly discusses in Book III, chapter 66 of Le istitutioni harmoniche: 'Similarly we may take any tenor and arrange it in fugue with another part in such a way that the voice which was the guide becomes the consequent and vice versa.' ${ }^{22}$ Zarlino illustrates this with two examples: Willaert's Venator lepores (on the cantus firmus Argentum et aurum non est mihi), published in his book of six-voice motets (Venice, 1542), and Zarlino's own In principio Deus. The latter piece, no. 8 of the Modulationes sex vocum, contains a two-part canon on the cantus firmus Omnis sapientia. With the verse 'Alternis dicetis, amant alterna Camenae' (Sing by turns, the Muses love responsive song), a quotation from Vergil's third Eclogue, Zarlino suggests a canon between Quintus and Altus at the upper fifth in the prima pars, and between Altus and Quintus at the lower fourth in the secunda pars.

The cryptic label 'Clavibus ingreditur, caetera cuncta patent' (Enter with the clefs, all the rest is revealed) that is attached to the Tenor of Misereris omnium signifies a canon at the upper fifth between this voice and the Altus (see Figure 3 above and Example 2). The initial c3 clef indicates a starting pitch on $g$, the subsequent $\mathrm{f} 3$ clef

22 Zarlino, Le istitutioni harmoniche, p. 265: 'Potremo simigliantemente pigliare alcun Tenore, ordinandolo con un'altra parte in Fuga in tal maniera; che volendo replicare le parti, facino una seconda parte, di modo, che quella che prima fù la Guida diventi il Consequente; \& similmente quella, che era il Consequente diventi la Guida.' Translation quoted from G. A. Marco and C. V. Palisca, Gioseffo Zarlino: The Art of Counterpoint. Part Three of Le istitutioni harmoniche, 1558 (New York, 1983), p. 237. 
Katelijne Schiltz

Table 2 Gioseffo Zarlino, Misereris omnium: layout of the canon

\begin{tabular}{lll}
\hline \hline Number of rests (in breves) & Number of breves & Text \\
\hline $11(14)$ & 7 & Ne reminiscaris Domine \\
4 & 6 & delicta mea \\
4 & 5 & vel parentum meorum \\
3 & 6 & neque vindictam sumas \\
4 & 6 & de peccatis meis \\
4 & 5 & neque vindictam sumas \\
2 & $5+3$ & de peccatis meis \\
\hline \hline
\end{tabular}

the starting pitch of the canonic voice on $c^{\prime}$. Although no strict mathematical pattern can be discovered in the construction of the canon, it is nevertheless striking that the number of rests and notes remains more or less equal in the course of the composition (see Table 2). Above all, Zarlino chooses to repeat the last two phrases ('neque vindictam sumas' and 'de peccatis meis') with an almost identical melodic and rhythmic layout.

Zarlino even added a third layer to Misereris omnium. The Quintus shows a short motif on the words 'Miserere mei Deus', which epitomise the central theme of the motet as a whole (see Figure 4). ${ }^{23}$ The musical treatment of this voice unequivocally refers to the Miserere tradition in general and to Josquin's Miserere mei Deus in particular. Its interpretation has to be deduced from the accompanying text: 'Rule. You who sing this should know that you must often repeat it: and each time you return one rest will desert you. On the first return you must descend a fourth; when you return, sing the voice under that at the fifth. Then you will have to ascend as often in the same order.'24 The soggetto, which consists of the value of three breves, is to be sung nine times, starting alternately on $e^{\prime}, b$ and $e$. The result is a palindromic pitch sequence. Between these statements, the number of rests systematically decreases (from nine to one), which not only creates an effect of acceleration, but also makes the cries for mercy increasingly penetrating (see Figure 5 and Table 3).

${ }^{23}$ In the manuscript Modena, Biblioteca Estense, MS C.314, which is the earliest source for Misereris omnium (see below), the soggetto is in the part labelled 'Altus', just as it is in the same (high) location in the Infelix ego settings by Willaert, Rore and Vicentino.

${ }^{24}$ Zarlino thus uses the term 'canon' here in its literal sense, i.e. as a rule ( $\left.\kappa \alpha v \omega v\right)$ that indicates how an unwritten part is to be deduced from a written one. 


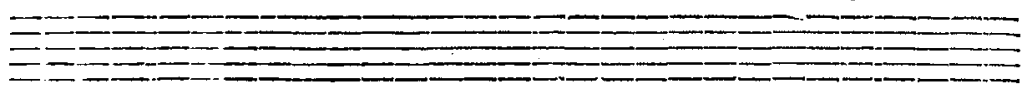

Canon. Qui canis hxe, iteranda fcias tibi frpius effe:

Semper \& in redicu, tempus te deferat unum.

AdQuartam in primo reditu def́cendere debes:

Ad Quintam ueniens iterum, cane uoce fub illa .

Deinde afcendendum toties erit ordine codem.

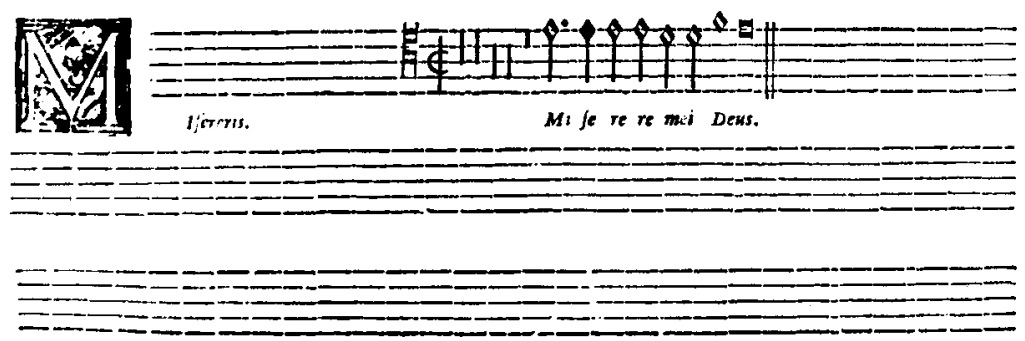

Figure 4 Gioseffo Zarlino, Misereris omnium: rubric for the soggetto ostinato. By permission of the Bayerische Staatsbibliothek München, Musikabteilung

Contrary to a procedure Willaert often used in his five- and six-part motets, ${ }^{25}$ Zarlino does not augment or diminish the note values of the soggetto, but maintains its design throughout the motet. The ostinato's rhythmic layout (Example 3a) is exactly twice the speed of Josquin's version (Example 3b). ${ }^{26}$ But whereas Josquin's soggetto consists of a series of repeated notes with a semitone inflection at the end on the syllable 'Deus', Zarlino writes a falling second on 'mei', which is then followed by a rising third on 'Deus'. This contour clearly follows Willaert's and Rore's treatment of the Miserere cantus firmus in their settings of Infelix ego, Girolamo Savonarola's meditation on Psalm 50 (see Examples 3c and 3d). ${ }^{27}$

${ }^{25}$ On this collection and the presence of soggetti ostinati, see K. Schiltz, 'Motets in their Place: Some "Crucial" Findings on Willaert's Book of Five-Part Motets (Venice, 1539)', Tijdschrift van de Koninklijke Vereniging voor Nederlandse Muziekgeschiedenis, 54 (2004), pp. 99-118.

${ }^{26}$ However, in the secunda pars of Josquin's Miserere mei Deus, the ostinato appears in faster note values.

27 Savonarola wrote this text in his Florentine prison cell, shortly before he died. This meditation became one of his most-printed works. For a modern edition of Willaert's and Rore's settings of Infelix ego, see Savonarolan Laude, ed. Macey, pp. 135-51 and C. de Rore, Opera omnia, ed. B. Meier (Corpus mensurabilis musicae,14; n.p., 1975), vi, pp. 184-95 respectively. I recently discovered that the soggetto ostinato in Willaert's Infelix ego was copied exactly (i.e. the same rhythm, melodic layout and structural organisation) in the Infelix ego setting of Agostino 

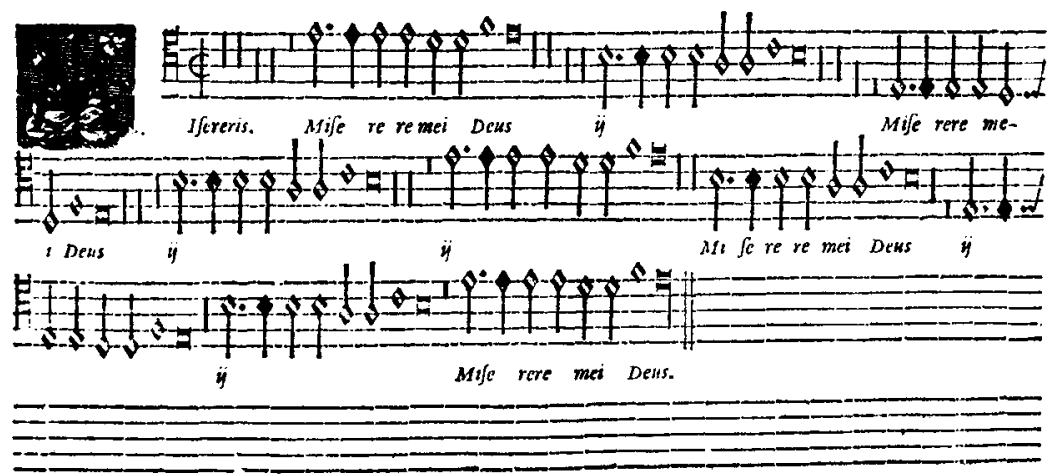

Figure 5 Gioseffo Zarlino, Misereris omnium: resolution of the soggetto ostinato. By permission of the Bayerische Staatsbibliothek München, Musikabteilung

Table 3 Gioseffo Zarlino, Misereris omnium: layout of the soggetto ostinato

\begin{tabular}{lll}
\hline \hline Number of rests (in breves) & Number of breves & Initial note \\
\hline 9 & 3 & $e^{\prime}$ \\
8 & 3 & $b$ \\
7 & 3 & $e$ \\
6 & 3 & $b$ \\
5 & 3 & $e^{\prime}$ \\
4 & 3 & $b$ \\
3 & 3 & $e$ \\
2 & 3 & $b$ \\
1 & $3+3$ & $e^{\prime}$ \\
Total: 45 rests & Total: 30 breves & \\
& Total number of breves: 75 & \\
\hline \hline
\end{tabular}

Bonzanino, an amateur musician and one of the founding members of the Accademia Filarmonica in Verona. Bonzanino's six-voice setting survives - albeit incompletely - in Verona, Accademia Filarmonica, MS 221. Apart from the soggetto ostinato, the other voices were newly composed by Bonzanino. I am grateful to Dr Inga Mai Groote for sharing a copy of this manuscript with me. 
(a)

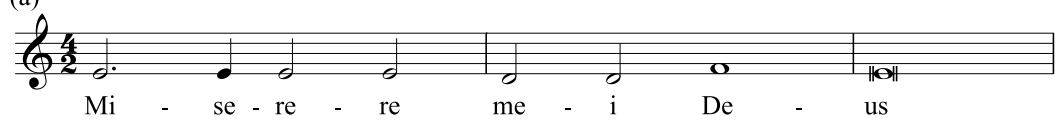

(b)

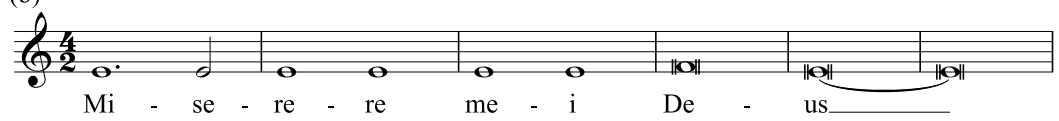

(c)

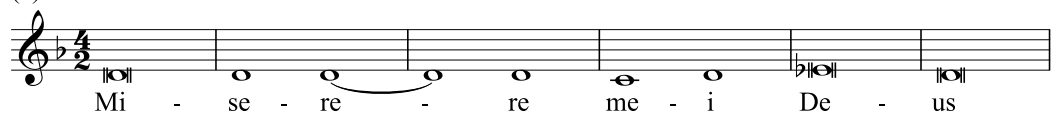

(d)

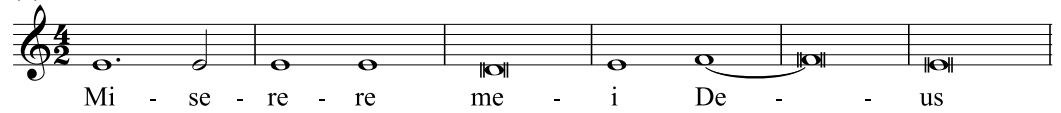

Example 3 Comparison of the soggetto ostinato: (a) Gioseffo Zarlino, Misereris omnium; (b) Josquin des Prez, Miserere mei Deus; (c) Adrian Willaert, Infelix ego; (d) Cipriano de Rore, Infelix ego

Paralleling the idea of meditation on the words 'have mercy', Zarlino's melodic outline, oscillating between $m i-r e-f a-m i$, is anticipated at the very beginning of the motet at the words 'Misereris omnium'. It is sung - albeit in longer note values - by Sextus (bars 1-4), Bassus (bars 3-6) and Cantus (bars 6-9), starting on $b, e$ and $e^{\prime}$ respectively (see Example 4). Structurally speaking, Zarlino's soggetto most closely resembles the prima pars of Rore's motet: he too presents the ostinato (consisting of six breves) nine times in the Altus, alternating between $e^{\prime}$ and $b^{\prime}$, but he maintains the number of rests between the statements (i.e. six). Josquin's Miserere mei Deus has an irregular number of rests between the entries of the ostinato.

At the point in the main text of Misereris omnium where the verses from the Wisdom of Solomon are followed by Psalm 56: 2 ('Miserere mei Deus, miserere mei: quoniam in te confidit anima mea'), Cantus, Sextus and Bassus join with the words and the music of the ostinato by imitating its basic features, either literally or with melodic and/or rhythmic changes: see, for example, the retrograde versions $a-b b-g-a$ in the Bassus (bars 46-8) and $b-c^{\prime}-a-b$ in the Cantus (bars 50-2) (see Example 5). In a time span of eighteen bars (bars 41-58), the words 'miserere mei Deus' are sung no fewer than 
Katelijne Schiltz
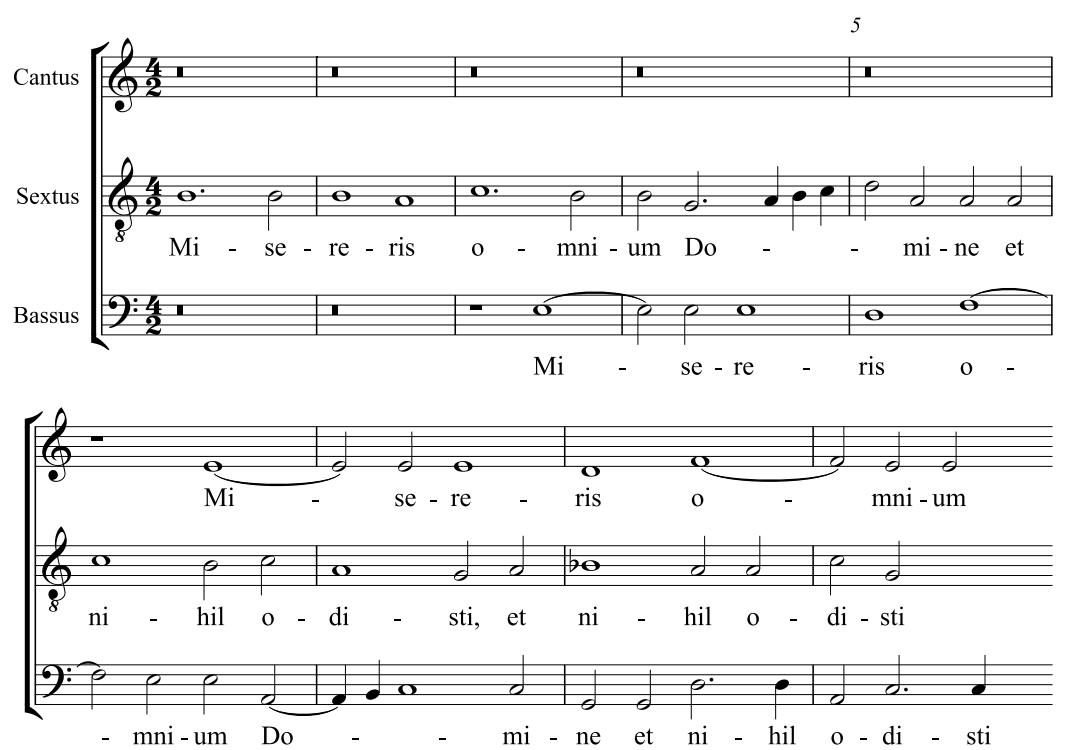

Example 4 Gioseffo Zarlino, Misereris omnium, bb. 1-9 (Cantus, Sextus and Bassus)

five times each by Cantus and Sextus, and four times by Bassus. ${ }^{28}$ The cry for mercy thus functions as a signal, which is picked up by the other voices.

A similar strategy emerges at the beginning of Zarlino's Miserere mei Deus. Here too, all voices - except for the two canonic parts allude to the Miserere topos on the first words of Psalm 56: 2 (see Example 6). The version in the Cantus (bars 1-3) and the Quintus (bars 4-6) is even a literal quotation of the ostinato Willaert and Rore presented in their Infelix ego settings (see Examples 3c and d above). Moreover, the opening of Miserere mei Deus echoes the conclusion of Rore's motet, where the soggetto enters in diminution and in stretto in all the voice parts (from bar 174 onwards). The fact that Zarlino opens his own composition with exactly the same soggetto (with the same rhythm and melodic outline) suggests that he wanted to pick up the thread of the music just where Rore leaves off. Rhythmically speaking, apart from the last note, the layout of

28 At the end of the work (bars 69-75), the words 'Miserere mei Deus' return once more in the main text. This time, Cantus, Sextus and Bassus each sing this text only twice. The soggetto is first doubled in tenths (bar 69), then thirds (bar 70) and finally sixths (bar 73). This procedure echoes the end of Willaert's Infelix ego, where Altus, Sextus, Tenor and Bassus present a homophonic declamation on 'Miserere mei Deus' (bars 170-2). 


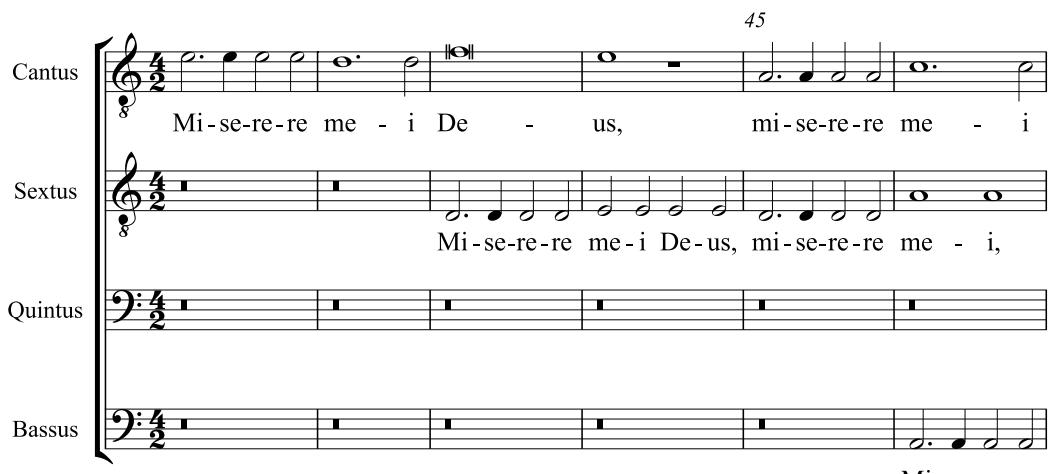

50

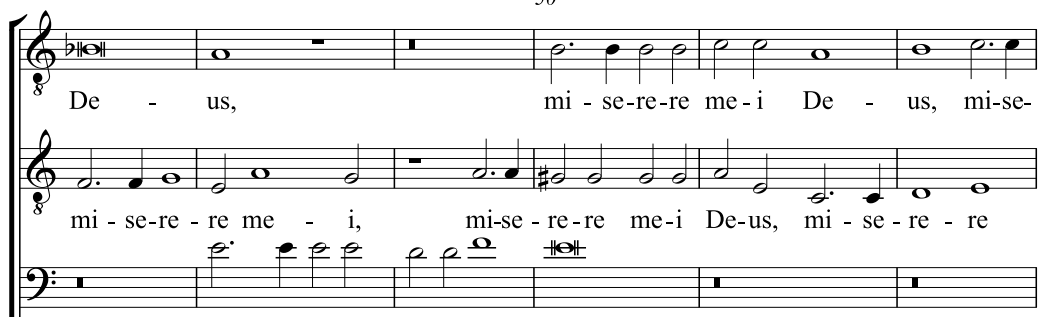

$$
\mathrm{Mi} \text { - se-re-re me-i De - us, }
$$

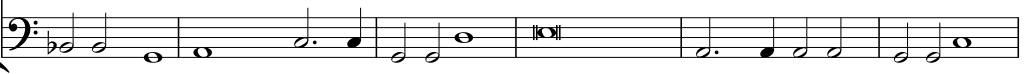

me-i De-us, mi-se-re-re me - i, mi - se-re-re me-i De -

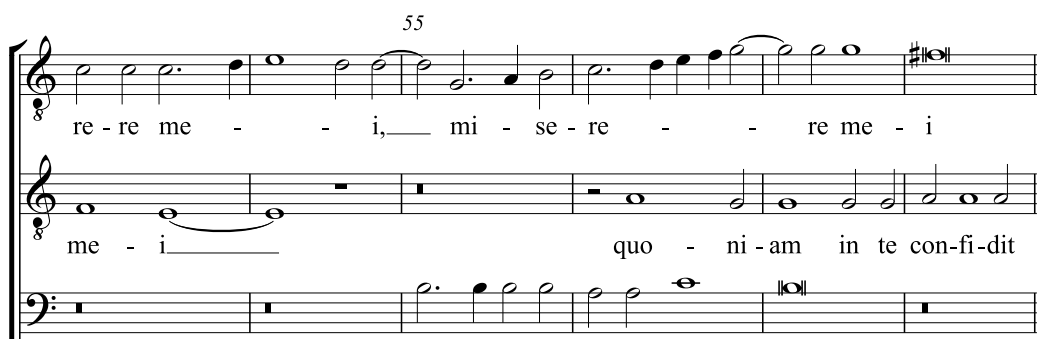

mi - se-re-re me-i De - us

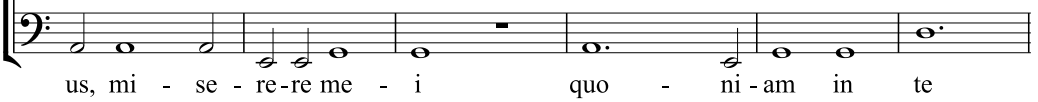

Example 5 Gioseffo Zarlino, Misereris omnium, bb. 41-58 (except canonic voices) 
Katelijne Schiltz
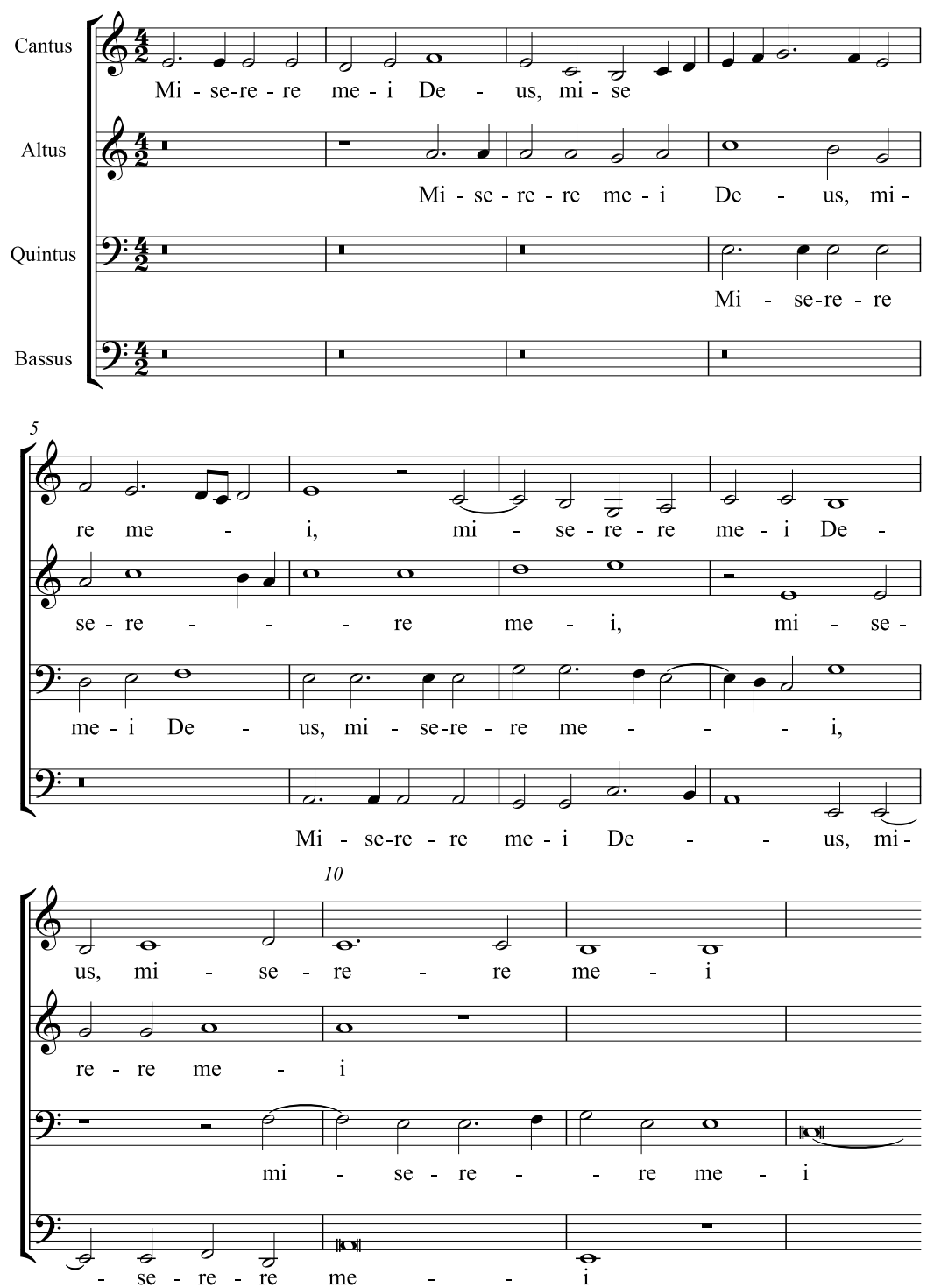

Example 6 Gioseffo Zarlino, Miserere mei Deus, beginning of prima pars (bb. 1-12; except canonic voices)

this motif is exactly the same as the ostinato of Misereris omnium (see Example 3a above). Interestingly enough, Zarlino continues the reference to the Miserere tradition at the beginning of the secunda pars 
Gioseffo Zarlino and the Miserere Tradition
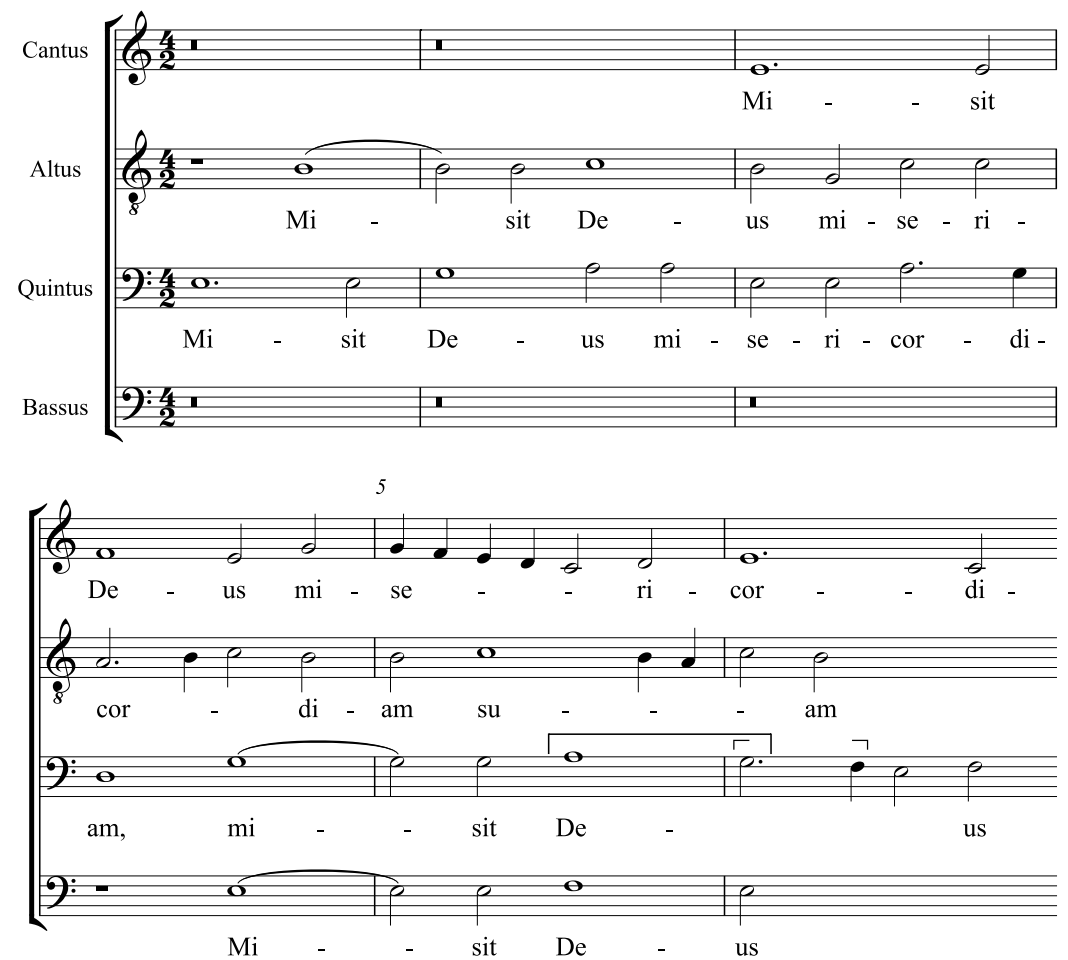

Example 7 Gioseffo Zarlino, Miserere mei Deus, beginning of secunda pars (bb. 1-6; except canonic voices)

(see Example 7). Here, it seems as if the sheer sound of the words 'Misit Deus' inspired him to write a motif with the semitone inflection $m i-f a-m i$ (see, for example, Cantus, bars 3-4), thus making it sound like a condensed version of Josquin's ostinato.

THE RELATIONSHIP BETWEEN THE MODULATIONES SEX VOCUM AND LE ISTITUTIONI HARMONICHE

It is clear that the connections between Miserere mei Deus and Misereris omnium are not incidental but were carefully planned by Zarlino. Further evidence of this comes from another source: the close relationship between the pieces is made explicitly in the revised edition of his Istitutioni harmoniche (Venice, 1573). Cristle Collins Judd has recently studied the sources and the role of Zarlino's exempla in 
the two editions (1558 and 1573) of this treatise. ${ }^{29}$ Elsewhere I have investigated the specific relationship between Le istitutioni harmoniche and the Modulationes sex vocum. ${ }^{30}$ It is striking to see that Zarlino already mentions many motets from this collection in the edition of 1558, although the pieces were not published until 1566. ${ }^{31}$ A similar case is the exempla taken from Willaert's Musica nova, which at the time of the treatise's appearance had not yet officially been published. ${ }^{32}$ Needless to say, this points to Zarlino's close involvement in the complicated publication history of Willaert's monumental collection, to which I shall return later. To a present-day readership, Zarlino's method is rather surprising: why exemplify theoretical concepts with compositions that are not yet accessible to a broader public? Zarlino undoubtedly belonged to an elite circle of connoisseurs, a fact he stresses more than once via his choice of exempla. However, his approach also underlines the fact that he was - as Judd puts it - a 'masterful manipulator of his printed persona'. ${ }^{33}$ Indeed, in his dedication of the Modulationes to the Procuratori di San Marco, Philippus Iusbertus (who had been hired as a singer at St Mark's in 1562) explicitly links these pieces to Zarlino's treatise, in order to show that the chapel master was an expert in both music theory and composition:

After that distinguished book to which he gave the title On the Institutes of Harmony in which he seems to discourse on the discipline of music with such learning and eloquence that no one yet (and let this be said with the indulgence of all) has treated this particular subject more clearly or fully, who is there that would not long for the second book of compositions? And all the more so, because he very frequently makes mention of these matters in the earlier book? Another motive is that all should understand that this same artist is able to discourse learnedly on the theoretical aspects of music and to produce the most lovely of all compositions. ${ }^{34}$

${ }^{29}$ See the comparative table in Judd, Reading Renaissance Music Theory, pp. 202-5.

${ }^{30}$ K. Schiltz, 'Exempla ducent': Von Zarlinos Institutioni harmoniche (1558) zu den modulationes sex vocum (1566)' (forthcoming).

31 The first edition of Le istitutioni harmoniche can be consulted online via Thesaurus Musicarum Italicarum: <http://euromusicology.cs.uu.nl/>.

32 The dedication by Francesco Dalla Viola is dated September 1558, but the title page carries the date 1559 .

${ }^{33}$ Judd, Reading Renaissance Music Theory, p. 188.

34 'Post illum librum cui titulum indidit De Institutionibus Harmonicis, in quo de musica disciplina ita docte pariter et diserte disputare videtur, ut nemo hactenus (quod pace omnium dictum esto) rem ipsam dilucidius, et copiosus tractaverit, quis est qui hunc alterum modulationum librum, non desiderat? idque eo maxime, quod plurimum de iis in superiore libro illo meminerit? Huc accedit illud, quo intelligant omnes, eiusdem artificis esse, et de Theoricis musicae docte disserere, et modulationes quasque suavissimas efficere posse.' 
In terms of the exempla, there are some major differences between the two editions of Le istitutioni harmoniche, a fact that also affects the two motets under discussion. In the version of 1558, Zarlino mentions only Miserere mei Deus, which suggests that Misereris omnium was composed at a later date (see below). Both motets are mentioned twice in the edition of 1573. In the fourth book of Le istitutioni harmoniche, which is dedicated to modal theory, Zarlino cites them side by side in his chapter on the Hypophrygian mode. ${ }^{35}$ After mentioning Josquin's De profundis, Willaert's Peccata mea Domine, Rompi dell'empio cor and Laura mia sacra, he adds: 'I, too, have written many compositions in this mode, among them the motet Miserere mei, Deus, miserere mei for six voices, and also Misereris omnium.'36 The third book of this treatise is devoted to counterpoint and compositional techniques and contains a long chapter with 'Alcuni avertimenti intorno le Compositioni, che si fanno à più di Tre voci'. One of the possibilities Zarlino discusses is the canonic treatment of a cantus firmus: '[Composers] also took a cantus firmus tenor and added to it (as is still done today) two or three parts in consequence, writing further parts upon these. ${ }^{37} \mathrm{He}$ also gives some advice about the compositional process of such cantus firmi: 'Such consequents should be and usually are written before the other parts are composed, but in writing them one must always keep the unwritten parts in mind and consider how they will fit into the texture; otherwise he will have double the work when he finds later that something goes wrong in the consequents.' 38 The first exempla Zarlino mentions are Willaert's seven-voice motets Verbum supernum

Translation quoted from Judd, Reading Renaissance Music Theory, p. 248. One might wonder why Iusbertus dedicates the edition; I agree with Cristle Collins Judd, who writes that the dedication deliberately and formulaically distances the print from Zarlino, but it is not hard to see Zarlino's hand in this extraordinary document' (ibid., p. 249).

${ }^{35}$ In the edition of 1558 , the discussion on the fourth mode is to be found in chapter 21. Owing to Zarlino's renumbering of the twelve modes in the edition of 1573, the Hypophrygian mode became the sixth mode (ch. 23).

${ }^{36}$ Zarlino, Le istitutioni harmoniche (Venice, 1573), p. 402: 'Composi ancora io molte cantilene, tra le quali si trova à sei voci il Motetto Miserere mei Deus, miserere mei: \& anco Misereris omnium Domine.'

37 Ibid., p. 325: 'Pigliavano anco un Tenore di canto fermo, sopra ilquale accommodavano (come fanno etiandio al d'hoggi) due, o Tre parti in Consequenza; \& dapoi sopra di quelle fanno l'altre' (Book III, ch. 66).

38 Zarlino, Le istitutioni harmoniche (1558), p. 265: 'Tali Consequenze si sogliono, \& si debbono veramente comporre, prima che si componghino le altre parti: ma bisogna haver sempre riguardo nel comporle, in qual maniera le parti, che si hanno da aggiungere, si possino accommodare nella cantilena: accioche non si habbia doppia fatica nel comporre tutto'l corpo 
(on the chant $O$ salutaris hostia) and Praeter rerum seriem (on the eponymous chant), which were to be published in his Musica nova. Zarlino then cites three of his own compositions: apart from the seven-voice Pater noster - Ave Maria, he provides some details about his Miserere mei Deus and Misereris omnium, focusing on their common affinities: 'Similar examples are the motets Miserere mei Deus, miserere mei on the antiphon Ne reminiscaris Domine; and on the same antiphon and on another Tenor, Miserere mei Deus, one can find the motet Misereris omnium Domine; I composed both of them for six voices.' ${ }^{39}$

Zarlino thus clearly stresses the double nature of Misereris omnium's pre-existent material, the cantus firmus being based on a Gregorian chant, the ostinato referring to Josquin's Miserere mei Deus and the web of intertextual relationships it initiated. ${ }^{40}$ These observations add a new twist to the interpretation of Zarlino's statements on the soggetto in general, as he explains it in Book III, chapter 26 of his Istitutioni harmoniche. There, he compares the method of a composer to that of a poet:

The poet's subject is [an incident of] history or a tale. Whether the story is of his own invention or borrowed from others, he adorns and polishes it with various embellishments as it pleases him. He omits nothing fit and suitable to delight the minds of his listeners, achieving thus something that is magnificent and marvelous. The musician has the same end, namely to serve and to please the minds of his listeners with harmonic accents, and he also has a subject upon which to construct his composition, which he adorns with various movements and harmonies to bring maximum pleasure

della Compositione quando venisse alcuna cosa di sinistro in tali Consequenze.' Translation quoted from Marco and Palisca, The Art of Counterpoint, p. 236.

It should be mentioned here that Zarlino treats canons more extensively in the 1573 edition of Le istitutioni harmoniche. In Bk. III, ch. 63, he offers detailed guidelines for constructing two-part canons over a cantus firmus: see D. Collins, 'Zarlino and Berardi as Teachers of Canon', Theoria, 7 (1993), pp. 103-23. One wonders whether Zarlino's decision might be linked to the publication of the Modulationes sex vocum. See also W. Horn, "Est modus in rebus ...": Gioseffo Zarlinos Musiktheorie und Kompositionslehre und das "Tonarten"Problem in der Musikwissenschaft' (unpublished Habilitationsschrift, Hochschule für Musik und Theater Hannover, 1996), pp. 170-85. I am grateful to Professor Horn for sharing the manuscript of his study with me.

${ }^{39}$ Le istitutioni harmoniche (1573), p. 325: 'Nella medesima maniera si ritrovano i motetti; Miserere mei Deus, miserere mei, sopra l'Antifona, Ne reminiscaris Domine; sopra laquale etiandio \& sopra un'altro Tenore, Miserere mei Deus si troverà composto il Motetto: Misereris omnium Domine: i quali composi à Sei: et la Oratione dominicale; Pater noster, con la Salutatione angelica Ave Maria: a Sette voci.' In the first edition of Le istitutioni harmoniche, Zarlino mentions Jachet of Mantua's Descendi in ortum meum for six voices (p. 264). In the version of 1573, this exemplum was substituted by his own Misereris omnium.

${ }^{40}$ Interestingly enough, Zarlino does not mention Josquin's motet in his Istitutioni harmoniche. 
to the audience. ${ }^{41}$

He then discusses the possible origins of the musical subject, stressing the rich choice of its pre-existent material and its further elaboration, both in terms of number of voices and compositional techniques:

The soggetto may be one of several kinds. It may be taken from a composition of another, fitted to his own and adorned by various parts, as he pleases to the best of his talent. Such a soggetto may be of several kinds: it may be a tenor or other plain-chant part, or a part from a polyphonic composition [canto figurato]. It may also consist of two or more voices, one of which may follow another in a fugue or consequence, or be organized in some other manner. Indeed, the types of such soggetti are potentially infinite in number. ${ }^{42}$

Through the double reference to the Miserere motif - via the soggetto ostinato of Misereris omnium on the one hand and the opening of Miserere mei Deus on the other - Zarlino must have had a firm intention. After Willaert, Rore, Vicentino and many others, he too wanted to be part of what had become a revered tradition by composing yet another variation on the Miserere theme. In a recent publication on the genesis of Zarlino's Si bona suscepimus, Cristle Collins Judd observes a similar working method:

Zarlino points to the possibility of composing out of a tradition or complex of works, thus giving the composer entry into a musical-discursive space through tangible connections to a group of other musical works. Such a framework of thought allows a compositional tradition's accumulation of utterances to serve as a model for the creation of a musical work, to create a contrapuntal grammar of the soggetto. ${ }^{43}$

41 Zarlino, Le istitutioni harmoniche (1558), p. 172: '[H]à nel suo Poema per soggetto la Historia, overo la Favola, la quale, o sia stata ritrovata da lui, overo se l'habbia pigliata da altrui: l'adorna, \& polisse . . . con varij costumi . . cosi il Musico, oltra che è mosso dallo istesso fine, cioè di giovare, \& di dilettare gli animi de gli ascoltanti con gli accenti harmonici, hà il Soggetto, sopra il quale è fondata la sua cantilena, laquale adorna con varie modulationi, \& varie harmonie, di modo che porge grato piacere a gli ascoltanti.' Translation quoted from Marco and Palisca, The Art of Counterpoint, p. 51.

42 Zarlino, Le istitutioni harmoniche (1558), p. 172: 'Et tal Soggetto può essere in molti modi: prima può essere inventione propia, cioè, che il Compositore l'haverà ritrovato col suo ingegno; dipoi può essere, che l'habbia pigliato dalle altrui compositioni, accommodandolo alla sua cantilena, \& adornandolo con varie parti, \& varie modulationi, come più gli aggrada, secondo la grandezza del suo ingegno. Et tal Soggetto si può ritrovare di più sorte: percioche può essere un Tenore, overo altra parte di qualunque cantilena di Canto fermo, overo di Canto figurato; overo potranno esser due, o più parti, che l'una seguiti l'altra in Fuga, o Consequenza, overo a qualunque altro modo: essendo che li varij modi di tali Soggetti sono infiniti.' Translation quoted from Marco and Palisca, The Art of Counterpoint, p. 52.

43 C. G. Judd, 'Learning to Compose in the 1540s: Gioseffo Zarlino's Si bona suscepimus', in S. Clark and E. E. Leach (eds.), Citation and Authority in Medieval and Renaissance Musical Culture: Learning from the Learned (Studies in Medieval and Renaissance Music, 4; Woodbridge, 2005), pp. 184-205, at 205. A similar response to an existing network can be seen in Zarlino's 
One might even say that with Misereris omnium, Zarlino wanted to emulate Josquin's famous model by embedding the ostinato in a texture with two other layers - the main text and the two-part canon - thereby creating a polytextual motet in the true sense of the word.

\section{ZARLINO AND DUKE ALFONSO II D'ESTE}

During the sixteenth century, other composers and theorists as well recognised the expressive and contemplative power of Josquin's Miserere mei Deus. ${ }^{44}$ In the preface to the Secundus tomus novi operis musici (Nuremberg, 1538), the German music publisher Johannes Ott not only stresses the piece's perfect symbiosis of words and music, but he also highlights the penetrating effect of the soggetto ostinato:

I ask whether anyone can listen to it so carelessly as not to be carried away in his whole mind and his whole spirit to a more careful contemplation of the prophet's meaning, seeing that the melodies are adapted to the feelings of the man who is overwhelmed by the magnitude of his sins and that the very powerful repetition in which he cries for mercy does not permit the mind either to consider these things at leisure or not to be aroused to the hope that comes from trust in the Lord. ${ }^{45}$

The humanist Heinrich Glarean also mentions Josquin's setting in Book III, chapter 20 of his Dodekachordon (Basel, 1547) and gives it a prominent place among the composer's oeuvre: 'This composition which Josquin des Prez has composed in five voices on the Psalm, Miserere mei Deus, has preference before all others. Its Tenor Secundus (as he calls it) has these three words, Miserere mei Deus, arranged with eight syllables to eight notes.' The theorist claims the piece to be so well known that in his exemplum he can reduce the soggetto to its very essence: 'However, because this song is in

seven-voice Pater noster - Ave Maria. In her paper "How to Assign Note Values to Words", Judd explored the context of Zarlino's setting within the polyphonic tradition stemming from Josquin's motet.

44 See also L. D. Brothers, 'On Music and Meditation in the Renaissance: Contemplative Prayer and Josquin's Miserere', Journal of Musicological Research, 12 (1992), pp. 157-87. In his Dum vastos Adriae, a tribute to Josquin, Jachet of Mantua counted Miserere mei, Deus among the composer's most famous works. See A. Dunning, 'Josquini antiquos, Musae, memoremus amores: A Mantuan Motet from 1554 in Homage to Josquin', Acta Musicologica, 41 (1969), pp. 108-16.

45 RISM 1538'3 : Eum quaeso, an quisquam tam negligenter audire potest, ut non simul toto animo, et mente tota feratur, ad sententiam Prophetae diligentius intuendam, cum et modi, ad affectus illius, qui peccatorum magnitudine premitur, conformati sint, et ista gravissima repetitio qua misericordiam implorat, non sinat animum, aut ociose ista cogitare, aut non excitari ad spem fiduciae' (translation [by Leofranc Holford-Strevens] quoted from Macey, 'Josquin and Musical Rhetoric', p. 493) (emphasis mine). 
everyone's hands we shall not arrange its tenor in groups of eight, as he did, but in groups of three, so that the reader may observe both ascent and descent with a single glance, as it were.' ${ }^{46}$

Josquin's motet, written about 1503 during his stay in Ferrara at the request of his patron Ercole I d'Este, ${ }^{47}$ seems to have had a particular significance at the Estense court, which endured long after the composer's death. Indeed, the Infelix ego settings by Willaert, Rore and Vicentino - who all served one or more Este rulers at a certain period their professional life - can be linked with specific members of this Ferrarese family: ${ }^{48}$ the first two motets were composed for Duke Ercole II, ${ }^{49}$ whereas Vicentino most likely completed his setting before 1561, when he left cardinal Ippolito II's service. ${ }^{50}$ All of these motets are written for six voices and quote Josquin's ostinato - either literally or with slight changes - in one part. It seems thus safe to assume that - as Patrick Macey puts it 'we can . . begin to see the outlines of an interesting pattern of Este patronage'. ${ }^{51}$ Moreover, Macey believes these motets 'most likely functioned as private music for the Este court'. ${ }^{52}$

In the case of Zarlino's Miserere mei Deus and Misereris omnium, a similar link with Ferrara has never been explored. ${ }^{53}$ Neither has the

46 'Sed ante omnia ea compositio, quam Iodocus Pratensis super Psalmum Miserere mei Deus: quinque instituit uocibus, palmam obtinet. In quo Tenor Secundus (ita enim appellat) tria haec uerba Miserere mei Deus, octonis et syllabis et notis habet. Verum quia haec cantio in omnium manu est, Tenorem eius non octonis, ut ille sed ternis notulis instituamus, ut Lector et ascensum et descensum, uno quasi aspectu intueatur.' Translation quoted from H. Glarean, Dodecachordon, ed. C. A. Miller (Musicological Studies and Documents, 6; n.p., 1965), pp. 259-60.

47 On Josquin and Ferrara, see among others L. Lockwood, 'Josquin at Ferrara: New Documents and Letters', in E. E. Lowinsky and B. J. Blackburn (eds.), Fosquin des Prez: Proceedings of the International Fosquin Festival-Conference Held at the Fuilliard School at Lincoln Center in New York City, 21-25 June 1971 (London, New York, and Toronto, 1976), pp. 103-37; P. Merkley, 'Josquin Desprez in Ferrara', Journal of Musicology, 18 (2001), pp. $544-83$.

48 On the history of the Este family, see L. Chiappini, Gli Estensi: Mille anni di storia (Ferrara, 2001).

49 Macey, Bonfire Songs, pp. 197 ff. believes Willaert composed his Infelix ego in the 1530s, a hypothesis he also connects with the religious and political situation in Ferrara at that time. Rore's setting must date from between 1546 (his arrival in Ferrara) and October 1559 (the death of Ercole II).

50 Macey, Bonfire Songs, pp. 235 ff. also discusses Palestrina's Tribularer si nescirem, which was published in his second book of motets for five, six and eight voices (Venice, 1572). This motet contains a soggetto ostinato on the words 'Miserere mei Deus' and was probably dedicated to his former patron Ippolito II d'Este.

51 Macey, 'Josquin's Miserere mei Deus', p. 26.

52 Macey, Bonfire Songs, p. 212.

53 In his dissertation, Macey discusses Zarlino's Misereris omnium (he does not mention Miserere mei Deus), but sees no connection with the Este court: 'It seems more likely that they [Zarlino and 
relationship between Zarlino and the Este court in general been investigated. However, for several decades the theorist and composer maintained close contacts with several members of this family, and in this context the pair of Miserere mei Deus and Misereris omnium settings plays an important role. Indeed, apart from their publication in the Modulationes sex vocum, both pieces already appear in the manuscript Modena, Biblioteca Estense, MS C.314, which incidentally or not - also contains Willaert's Infelix ego. ${ }^{54}$ According to Jessie Ann Owens, these luxurious and elegantly bound partbooks were probably written in Ferrara around $1560 .{ }^{55}$ If this hypothesis is correct, Misereris omnium (see Figure 6) must have been composed between 1558 (the publication of the first edition of Le istitutioni harmoniche, in which the motet is not yet mentioned) and c. 1560, thus pre-dating the Modulationes sex vocum by about six to eight years. ${ }^{56}$ One might even speculate that Misereris omnium was explicitly written to be included in the prestigious Este manuscript: since the partbooks were used at the ducal chapel and contain music by composers who either served the Este court or had good contacts with it, the pieces must have had a special significance for Duke Alfonso II (1533-97). This is also confirmed by the fact that the manuscripts G.313 and C.314 contain many motets from Willaert's

Jacquet de Berchem] incorporated Josquin's soggetto as a generalized expression of penitence' (p. 178).

${ }^{54}$ Curiously, the inscriptions for the canons and the soggetto ostinato are lacking. Moreover, both Misereris omnium and Miserere mei Deus are notated a fourth higher (E Phrygian transposed up to A) than in the Modulationes sex vocum. Above all, as I have pointed out above, in the case of Misereris omnium the soggetto is in the part labelled 'Altus' (Modulationes: Quintus), just as it is in the Infelix ego settings by Willaert, Rore and Vicentino. By relabelling the parts in the Modulationes sex vocum, the intertextuality with their works is obscured. Apart from Miserere mei Deus (no. 17) and Misereris omnium (no. 23), the manuscript partbooks (and their companion, MS C.313) also contain two other motets by Zarlino: Si bona suscepimus (no. 54 of C.313) and Ascendo ad patrem (no. 7), which were published in his Musici quinque vocum moduli and Modulationes sex vocum respectively. For a general survey of the original Catalogus estensium manuscriptorum codicum, compiled between 1754 and 1757 by Giovanni Antonio Panelli and Pellegrino Niccolò Loschi, see A. Chiarelli, I codici di musica della raccolta estense: Ricostruzione dall'inventario settecentesco (Quaderni della Rivista Italiana di Musicologia, 16; Florence, 1987).

55 J. A. Owens, 'An Illuminated Manuscript of Motets by Cipriano de Rore (München, Bayerische Staatsbibliothek, Mus. Ms. B)' (Ph.D. diss., Princeton University, 1979), p. 67. She believes the manuscripts to be the work of Ernando Bustamente, who (together with his brother Domenico) was paid as a singer at the Este court from 1560 onwards; see also A. A. Newcomb, 'The Musica secreta of Ferrara in the 1580's' (Ph.D. diss., Princeton University, 1969), p. 228.

56 The composition of Miserere mei Deus pre-dates the manuscript, since it was already mentioned in the first edition of Zarlino's Istitutioni harmoniche. 


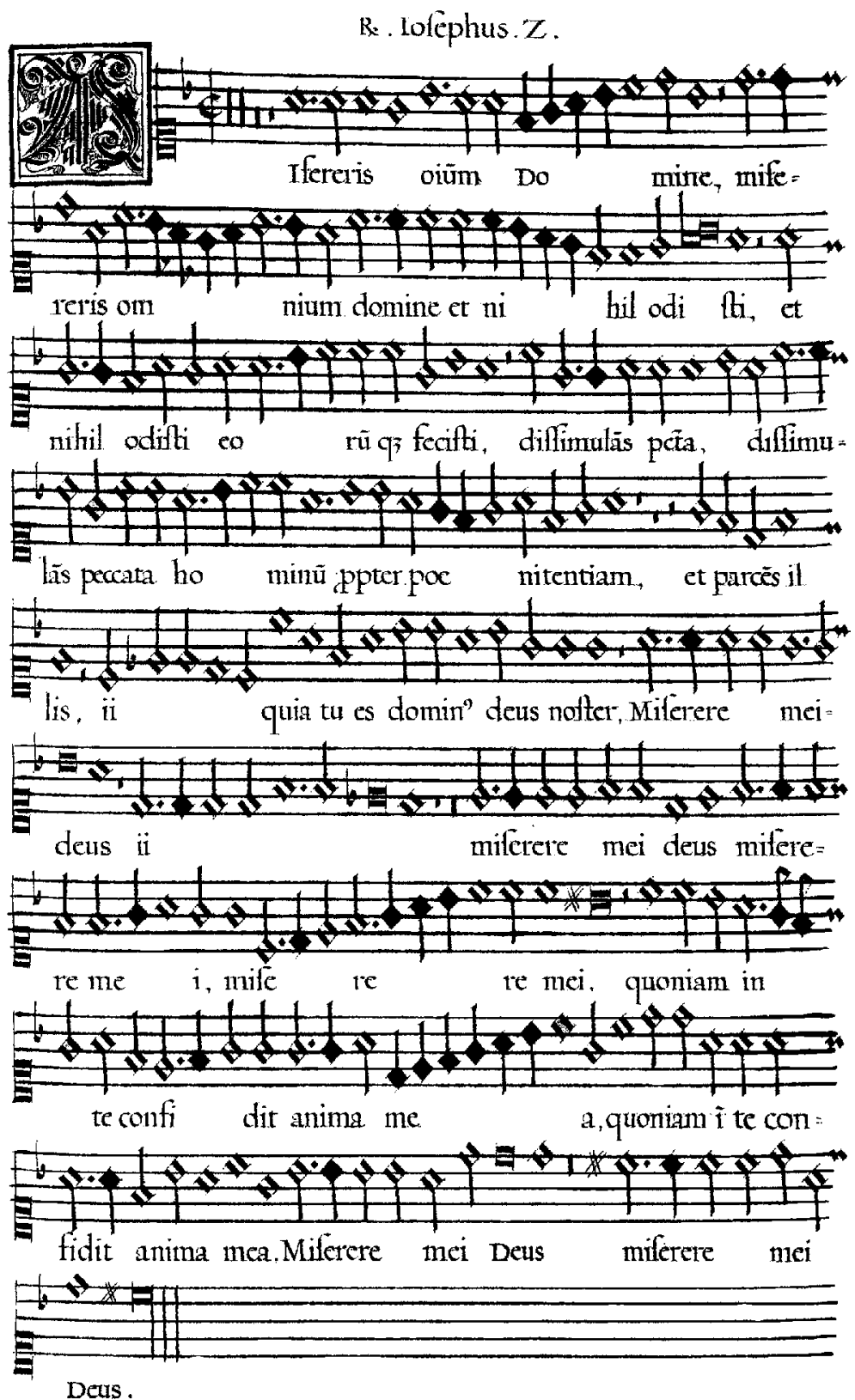

Figure 6 Gioseffo Zarlino, Misereris omnium, Cantus. Modena, Biblioteca Estense, MSC.314. By permission of the Biblioteca Estense, Modena and the Ministero per i Beni e le Attività Culturali 
Musica nova, whose format (upright quarto) and general aspect they seem to imitate. ${ }^{57}$

Archival research by Jessie Ann Owens and Richard Agee has shown that Zarlino was closely involved in the publication history of Willaert's Musica nova. It is known that the music circulated privately for some twenty years before it was printed in 1559 by Antonio Gardano. In 1554, Alfonso d'Este obtained the unique manuscript of Willaert's music from the singer Polissena Pecorina. A contract was made, but although this source is lost, a document from August 1572 (regarding a private agreement between Duke Alfonso and Pecorina's heirs) tells us that Zarlino was present as a witness at the transaction. ${ }^{58}$ A few years later, in 1558, the publication of Musica nova was threatened by a conflict between Alfonso and the nobleman Antonio Zantani, who planned to print four of Willaert's madrigals in the collection Le eletta di tutta la musica prior to their publication in Musica nova. Alfonso, who wanted to be the sole owner of the music, took the matter very seriously and engaged several persons - he even involved his father, Duke Ercole II - to solve the problem. From a letter Zantani wrote to Girolamo Faleti (Alfonso's Venetian ambassador) we learn that both Gardano and Zarlino had been asked to defend Alfonso's case. ${ }^{59}$ A letter from Alfonso's secretary Giovanni Battista Pigna to Faleti again stresses the

57 One of these, the six-voice Mittit ad virginem, served as the model for Willaert's eponymous parody mass. The unique source for the Missa Mittit ad virginem is the manuscript Modena, Biblioteca Estense e universitaria, MS $\alpha . N .1 .1$, copied in Ferrara for the ducal court of Alfonso II. The seven-voice Agnus Dei contains a mensuration canon on the words 'Pater Alphonso annue secundo Duci Ferrariae', which helps to establish a terminus post quem for its composition: since the date of accession of Alfonso II as Duke was 1559, the mass must have been composed in that year or later. Cf. H. Beck, 'Adrian Willaerts Motette Mittit ad Virginem und seine gleichnamige Parodiemesse', Archiv für Musikwissenschaft, 18 (1961), pp. 195-204 and D. Kidger, 'The Masses of Adrian Willaert: A Critical Study of Sources, Style and Context' (Ph.D. diss., Harvard University, 1998), pp. 126-8. The same manuscript also contains a Missa Veni sancte spiritus by Francesco Dalla Viola in praise of Alfonso. The Tenor of the Sanctus carries the words 'Inclitae Ferrariae Alphonso Duci quinto laeta longa secula'.

58 See document 75 in J. A. Owens and R. J. Agee, 'La stampa della "Musica Nova" di Willaert', Rivista Italiana di Musicologia, 24 (1989), pp. 218-305, at 295: 'Io pre Gioseffo Zarlino Clodensis fui presente et son testimonio di quanto di sopra è scritto.'

59 Ibid., p. 274 (document 45, 6 December 1558): 'Io non harei mai pensato che V. S. mi fese dispiacer né cosa che per lei mi dolese o dese fastidio che a peticion de certi mecanici come è il Gardana, Pre Isepo Zerlin, senza averme mai fato intender cosa alcuna . . . . It should be mentioned here that Faleti is the author of the text of Cipriano de Rore's Hesperiae cum laeta, based on a Venus painting by Girolamo da Carpi: see E. E. Lowinsky, 'Cipriano de Rore's Venus Motet: Its Poetic and Pictorial Sources', in his Music in the Culture of the Renaissance and Other Essays, ed. B. J. Blackburn (Chicago and London, 1989), ii, pp. 575-94. 
importance of Willaert's music for Alfonso: 'Concerning this matter His Excellency is in a rage, and I do not doubt that if things do not go differently, there will be the most serious displeasure because he has perhaps this music more at heart than anyone could imagine who is not involved.' 60 It was only in April 1559 that a satisfactory arrangement between the two parties was reached. In his dedication to Alfonso d'Este, Francesco Dalla Viola clearly refers to the many obstacles the publication of Musica nova had to cope with:

At a time when the Musica nova by Adrian Willaert was hidden and buried in such a way that nobody could use it and the world was deprived of such beautiful compositions, during the past years Your Excellency made sure that he not only possessed it, but also saw to it that the same author revised and corrected the music in such a very mature way that everybody endlessly desires to see it, some to enjoy it, others to make use of it for their own compositions. One can indeed say that by the revision it had the beginning, the increase and almost the completion at the same time from the composer himself. One knows that, whenever this music is heard, it produces all those emotions in the heart that it wants to move and that it is most worthy of being imitated. And because I know that it will please Your Excellency to bring it to light for everyone's benefit, having received it from you as a gift, I have wished to take on the task of getting it published. Because I know that one of the great princes and one of the great composers are coming together in this edition, I have done everything - as far as my weak powers allowed me - to see that the print is consistent with them in some manner, and all the more am I moved to do so, because the former is my patron, the latter my master. ${ }^{61}$

\section{In the first part of his Dimostrationi harmoniche (Venice, 1571),} Gioseffo Zarlino also alludes to the publication history of Willaert's Musica nova and Alfonso's extraordinary efforts to protect Willaert's

60 Owens and Agee, 'La stampa', p. 275 (document 47, 20 December 1558): 'Intorno a che S. Ecc. Mostra d'essere molto in colera. Et non dubito punto che se le cose non andranno per lo verso loro, che ne succederà un gravissimo suo sdegno perché ha forse più a cuore questa musica di quello che si possa imaginare chi non è stato in proprio fatto.' Pigna dedicated his Historia de principi di Este (Ferrara, 1570) to Alfonso II.

61 'Essendo la Musica nova di M. Adriano Vuillaert nascosta \& sepolta di modo, che alcuno non se ne potea valere, \& il mondo venea à restar privo di cosi bella compositione, V. Eccellenza tenne strada questi anni passati, che non solamente l'hebbe, ma ancora fece, che l'istesso autore la rivide, \& corresse molto maturamente, tal ch'ogn'uno desidera infinitamente di vederla, altri per pigliarne dilettatione, \& altri per servirsene al comporre; essendo che si puo dire, che nell'essere con buon ordine ridrizzata, habbia havuto il principio l'accrescimento, \& quasi la perfettione ad un tempo medesimo dall'istesso compositore; \& si conosce, che ad ogni sua richiesta fa sentir nell'animo tutti gli affetti, che si propone di muovere, \& che è dignissima d'essere imitata. Et perche io sò, che per questo rispetto sarà molto caro à V. Eccellenza, ch'essa à publico beneficio sia posta in luce, havendola io havuta in dono da lei, hò anchor io voluto pigliar la fatica di publicarla. Et conoscendo, che uno de maggior Prencipi, \& uno de maggior Musici concorrevano in questa impresa, mi sono ingegnato di fare, che per quanto comportano le mie deboli forze la stampa, in qualche parte, loro corrisponda. \& tanto più vivamente à ciò mi son mosso essendomi l'uno Patrone, \& l'altro Maestro.' 
music. The setting of this treatise is the state visit Duke Alfonso II paid to Venice in April 1562:

The year of our salvation had already reached the number 1562 and it was in the month of April when the Illustrious Alfonso d'Este, Duke of Ferrara . . . came to Venice. There he was received by our Illustrious Venetians ... with great pomp and circumstance. This Lordship had brought with him the best of his musicians, among whom ... was Francesco Viola, his chapel master and my dear friend. ${ }^{62}$

Zarlino reports that he and Dalla Viola went to hear Vespers at St Mark's, where they met Claudio Merulo, 'soavissimo Organista del detto tempio'. The three of them then decided to see Willaert, who 'did not leave his house because he suffered from gout'. ${ }^{63}$ Zarlino relates how, shortly before, Duke Alfonso himself had visited the chapel master and how they 'commemorated the courtesy his Lordship had shown [towards Willaert], and how dear his compositions were to him, and how through him a large part of the compositions, which he had composed and which remained almost buried, had come to light'. Using almost the same wording as Dalla Viola in his dedication, Zarlino stresses Alfonso's role in rescuing Willaert's Musica nova from being 'hidden and buried'. ${ }^{64}$

Alfonso's visit to Venice has been described in various other documents, such as Camillo Zio's La solennissima entrata dell'Illustrissimo, Ë Eccellentissimo Signor Duca di Ferrara, ne la Città di Venetia (Bologna, 1562) and Natale Conti's L'entrata che fece in Vinegia, l'Illustrissimo et Eccellentissimo S. Duca Alfonso II. Estense duca V. di Ferrara (Venice, 1562). These sources are interesting because of their day-by-day description of the festivities. ${ }^{65}$ Near the end of Conti's print, between two panegyric poems (Lodovico Dolce's Perche cosi tranquille e pure l'onde and Conti's own Obstupuere Dei pelagi, Tritonia

62 Zarlino, Dimostrationi harmoniche, p. 1: 'Gli anni di nostra salute erano gia pervenuti al numero di MDLXII. \& era il mese di Aprile: quando l'illustrissimo Sign. Donno Alfonso d'Este Duca di Ferrara ... vene à Vinegia. Onde dalli nostri Sign. Illustrissimi Venetiani con solennissima pompa, \& regali apparati . . . fù ricevuto. Havea questo Sig. seco menati i miglior Musici, che appresso di lui si ritrovavano: tra i quali ... era Francesco Viola suo maestro di capella, \& mio singolare amico.'

63 Ibid., p. 1: 'percioche molestato dalle podagre, non si partiva di casa'.

64 Ibid., pp. 1-2: 'i quali commemoravano le cortesie, che questo Sig. eccellente molte volte usato gl'havea: et quanto care gli erano le sue compositioni: \& come per lui erano venute à luce una grandissima parte di quelle cose, che egli havea gia composto; le quali stavano quasi sepolte'.

65 I am most grateful to Camilla Cavicchi for providing a copy of Zio's print from the Biblioteca Universitaria in Bologna. Conti's L'entrata is also accessible online: see < http://special-1.bl.uk/ treasures/festivalbooks>. It is worth noting that Francesco Rampazetto, who printed Zarlino's Modulationes sex vocum, also issued this publication. 
pubes) is a list of persons who accompanied the Duke during his Venetian visit. Among them were forty-two 'musici per la cappella, e per la camera', under the direction of Francesco Dalla Viola, who had succeeded Cipriano de Rore as chapel master of Alfonso's court in 1559. Music was sung at many occasions: in St Mark's, at the Palazzo Ducale, on the Canal Grande, etc. One evening, Alfonso received the Venetian dignitaries in his palazzo: 'On Saturday ... the Doge, together with the Signoria and the Senate, visited the Duke at his home. He received them in the Loggia that faces the Canal with a marvellous concert and music for all kinds of instruments; it took about two hours with a harmony that was exceedingly refined.' 66 Interestingly enough, Zarlino also contributed a piece for the festivities surrounding Alfonso's Venetian visit: he composed the celebratory motet Parcius Estenses proavos Ferraria Clara sit innumeris maiorum, which was to be published in the Primo libro de gli eterni mottetti (Venice, 1567). ${ }^{67}$ Unfortunately, only the Altus partbook of this print survives, which makes it impossible to provide stylistic details of the piece (see Figure 7). ${ }^{68}$ The poem, which Zarlino may have written himself, is composed in elegiac distichs, its prima pars echoing the first poem of Martial's Liber spectaculorum, where it is said that the Flavian amphitheatre surpasses the Wonders of the World: 69

66 N. Conti, L'entrata che fece in Vinegia (Venice, 1562), fol. $7^{\mathrm{r}}$ : 'Il sabbato . . il Doge con tutta la Signoria e Senato andò a visitare a casa Il S. Duca: ove egli lo ricevette nella gran Loggia, che riguarda il canale con un concerto maraviglioso di Musica di varie sorti d'istromenti: laqual durò d'intorno a due hore con una harmonia per certo rarissima.' See also D. Bryant, 'Alcune osservazioni preliminari sulle notizie musicali nelle relazioni degli ambasciatori stranieri a Venezia', in F. Degrada (ed.), Andrea Gabrieli e il suo tempo: Atti del convegno internazionale (Venezia 16-18 settembre 1985) (Florence, 1987), pp. 181-92.

67 D. Bryant, 'Musica e musicisti', in G. Cozzi and P. Prodi (eds.), Storia di Venezia dalle origini alla caduta della Serenissima, vol. 6 (Rome, 1997), pp. 449-67, at 450 and 454.

68 RISM $1567^{3}$. The Altus partbook is kept in Rome, Biblioteca del Conservatorio di Musica Santa Cecilia (shelfmark A.CS.1.c.50). As can be deduced from this voice, the composition is characterised by a careful text underlay and a syllabic declamation. According to Giulio Bonagiunta's dedication to Sigismondo Borgaso (a canon from Treviso), the print contains compositions by 'eccellentissimi Musici de rari dell'età nostra'. Zarlino's Parcius Estenses - Clara sit (no. 5 on pp. 8-9) is the only secular piece in the collection.

69 Martial, Spect. 1: 'Barbara pyramidum sileat miracula Memphis, / Assyrius iactet nec Babylona labor, nec Triuiae templo molles laudentur Iones: / dissimulet Delon cornibus ara frequens / aëre nec uacuo pendentia Mausolea / laudibus inmodicis Cares in astra ferant. / Omnis Caesareo cedit labor amphitheatro: unum pro cunctis fama loquetur opus' (Let barbarous Memphis stop talking about the miracle of the pyramids; Assyrian toil is not to vaunt Babylon, and the soft Ionians are not to garner praise for Trivia's temple; let the altar of many horns say nothing about Delos, and do not let the Carians lavish extravagant praise on the Mausoleum suspended in empty air and exalt it to the stars. All labour yields to Caesar's amphitheatre: 
Katelijne Schiltz
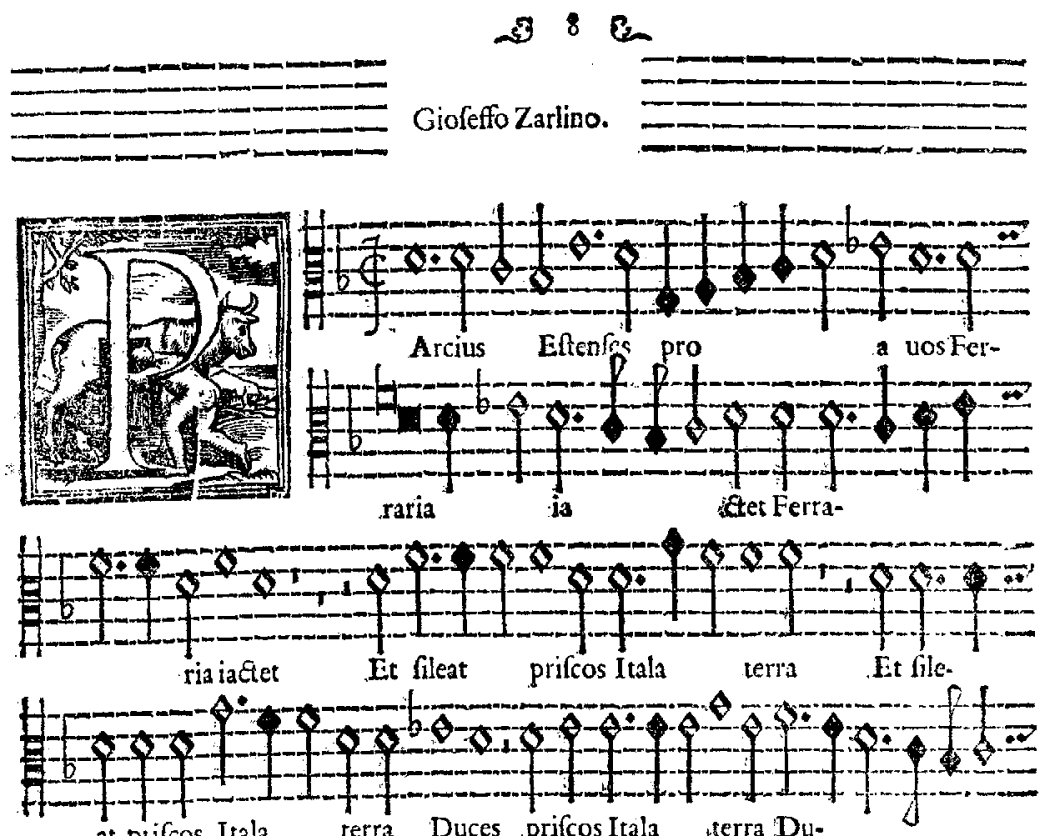
at piifcos Itala terra Duces prifcos Itala serra Du-

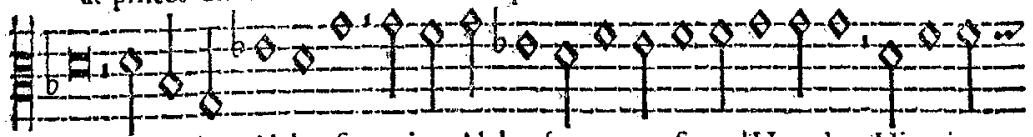

ces:Hic erit Alphonfus erit Alphonfus magnofatus."Hercule Hic erit
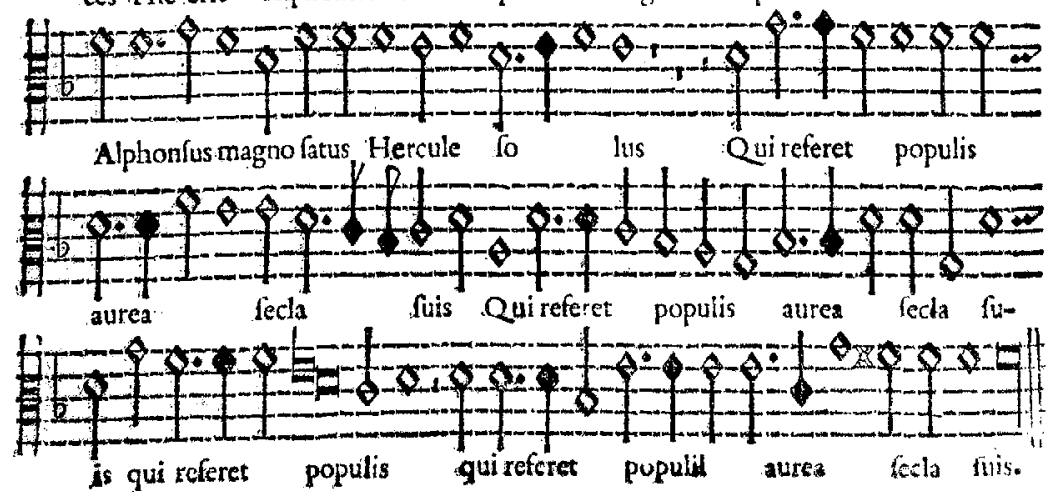

Figure 7 Gioseffo Zarlino, Parcius Estenses from Primo libro de gli eterni mottetti (Venice, 1567): prima pars. By permission of the Biblioteca del Conservatorio di Musica Santa Cecilia, Rome 
Prima pars

Parcius Estenses proavos Ferraria iactet

Et sileat priscos Itala terra Duces

Hic erit Alphonsus magno satus Hercule solus

Qui referet populis aurea secla suis.

Secunda pars

Clara sit innumeris maiorum fama tropheis

Maior hic aeterno faedere pacis erit

Obvia quid cessas Venetorum curia patrum

En venit Eoo qualis ab orbe dies.

Let Ferrara be more sparing in her boasts of her Este forefathers, and the land of Italy be silent about her ancient dukes: this Alfonso, born of the great Ercole, shall alone be he that brings back the golden age to his peoples.

Though his forebears' renown be illustrious for their countless trophies, he will be greater for the everlasting pact of peace; why do you tarry on your way to meet him, senate of the Venetians? Lo, he comes as gorgeous as the day comes from the east. (Translation: Leofranc Holford-Strevens)

Parcius Estenses is one of the few secular motets by Zarlino that (partially) survive. The collection Musici quinque vocum moduli of 1549 also contains two non-sacred texts, which may well have been written by the composer. They appear to have been connected to specific people and events: Clodia quem genuit - Ipsae et castalio is a lament on the death of Marchesino Vacca of Chioggia in 1546, wheareas Aptabo cythare modos - Nobis te duce, written the style of a Horatian epode, is more elusive in its reference to classical mythology. ${ }^{70}$ However, we do know that Zarlino composed further civic motets, especially after his appointment as chapel master of St Mark's in 1565. One of these occasions was the Venetian visit of King Henry III of France in $1574 .{ }^{71}$ Zarlino, who was in charge of

Fame will tell of one work instead of them all). Text and translation quoted from Kathleen M. Coleman, M. Valerii Martialis Liber Spectaculorum (Oxford, 2006), p. 1. I am grateful to Sven Lorenz for pointing out the intertextuality with Martial's poem.

${ }^{70}$ See Zarlino, Motets from 1549 Part 2, ed. Judd, pp. xxviii-xix (texts and translations) and pp. 70-9 and 80-6 (music) respectively.

71 See also D. Nutter, 'A Tragedy for Henry III of France, Venice, 1574', in A. Morrogh, F. Superbi Gioffredi, P. Morselli and E. Borsook (eds.), Renaissance Studies in Honor of Craig Hugh Smyth, vol. 1 (Florence 1985), pp. 591-611, and Iain Fenlon, The Ceremonial City: History, Memory and Myth in Renaissance Venice (New Haven, 2007). Zarlino probably also composed music for the Venetian celebration of the victory over the Turks at Lepanto in 1571: see I. Fenlon, 'In destructione Turcharum: The Victory of Lepanto in Sixteenth-Century Music and Letters', in Degrada (ed.), Andrea Gabrieli e il suo tempo, pp. 293-317 and id., 'Lepanto: The Arts of Celebration in Renaissance Venice', Proceedings of the British Academy, 73 (1987), pp. 201-36. It should be mentioned here that the Ferrarese ambassador Claudio Ariosti wrote a report of these celebrations to Alfonso II d'Este on 26 December 1571 (mentioned in Fenlon, 'Lepanto: The Arts of Celebration', p. 225). 
the music for these festivities, composed a secular motet on Cornelio Frangipagine's humanistic text Sternitur Hadriacum cui nam tot navibus aequor?, a dialogue between the sea nymph Nais and Hospes (i.e. Venice). The poem was published in Nicolò Lucangeli's Successi del viaggio d'Henrico III (Venice, 1574);72 unfortunately, the music is lost. Judging from the description in Frangipane's Tragedia, this piece was performed when the king boarded the Bucintoro on Sunday 18 July. ${ }^{73}$ The reason why I mention this particular state visit is that we know that Duke Alfonso II d'Este was also in Venice during these festivities. His presence might have been yet another opportunity for Zarlino to meet Alfonso, or at least to have the Duke listen to one or more of Zarlino's compositions. It is said that Henry III and Alfonso met several times and heard music on various occasions. On the evening of the king's arrival at Murano, they even visited Venice secretly:

With different garments he silently boarded an unknown gondola in the company of the Duke of Ferrara and had them brought to Venice ... When he returned to Murano, he enjoyed a most sweet and rare concert with voices and all kinds of instruments, which delighted the hearts of the audience with the sweetest ecstasy, and they wished nothing more, because to wish more was simply not possible. ${ }^{74}$

\section{ZARLINO AND LEONORA D'ESTE}

Apart from Alfonso d'Este, Zarlino also had good relations with other members of the Este family. In 1583 he dedicated (posthumously) his small treatise Utilissimo trattato della patientia, a tutti quelli che desiderano vivere christianemente to 'Suor Leonora d'Este' (1515-75), the daughter of Alfonso I and Lucrezia Borgia. It is a moral text, consisting of thirty-three chapters, in which he tries to bear his

72 N. Lucangeli, Successi del viaggio d'Henrico III. christianissimo Re di Francia, e di Polonia, dalla sua partita di Craccovia fino all'arrivo in Turino (Venice, 1574), p. 32.

73 'Monsignor Gioseffo Zarlino, il qual è stato occupato nelle musiche che hanno incontrato il re nel Bucentoro, che sono stati alcuni miei versi latini ...' (quoted after Nutter, 'A Tragedy', p. 596).

74 '[C] on habito diverso tacitamente montò in una gondola incognita, in compagnia del Duca di Ferrara, et si fece condurre a Venetia . . Tornato a Murano, hebbe a gustare una dolcissima et rara musica, tanto di voci humane quanto di variati istrumenti, per la quale gli animi degli ascoltanti erano rapiti da soavissima estasi et non desideravano più perché più desiderar non era lecito': see T. Porcacchi, Le attioni d'Arrigo terzo (Venice, 1574), quoted after Nutter, 'A Tragedy', p. 595. G. Leonfiero, Gl'honori fatti nello Stato di Venetia, ad Henrico Terzo christianissimo Re di Francia, et Pollonia (Rome, 1574) also frequently mentions the presence of Alfonso II d'Este in Venice during the King's visit. 
mother's death and to put his trust in God. ${ }^{75}$ From the dedication it appears that Zarlino and Leonora had known each other for quite some time: 'In this way, by dedicating my small work to You, I could show Your Illustrious and Reverend ladyship the devotion and the veneration that already many years ago I have conceived in my soul towards You for Your extraordinary qualities ....76 Their long-term acquaintance receives additional support from another source. Indeed, as we can read in Book VIII, chapter 3 of Zarlino's Sopplimenti musicali (Venice, 1588), it was Leonora d'Este who provided the initial impetus to write what was to become his last major treatise. More specifically, in the early 1570 s - which must have been shortly after the completion of the Dimostrationi harmoniche - she seems to have encouraged him to investigate the possible similarities between the 'Hidraulica machina', as it was described by Vitruvius in his De architectura (Bk. X, ch. 8, §§3-6), and the organ:

The similarities ... between the hydraulis and our organ led the Illustrious Sister Leonora d'Este in November of the year 1571 to ask me - via my dear friend Francesco Viola - whether that organ was old or rather new, and where its name came from. After I had first answered her, I was moved by this question and I decided to write the present Sopplementi, but not in the order as they appear now, but as the thoughts came or according to the time that certain things were being asked of me, like a wood, in which many trees are planted haphazardly and without any order. And this was the first question why I wrote for this purpose. Hence I shall place it here following, to satisfy the curiosity of those who wanted to know more about this matter. ${ }^{77}$

Recent archival research by Camilla Cavicchi has brought to light several documents that testify to Leonora d'Este's fascination with music in general and keyboard instruments and the organ in

75 As it happens, 'Patientia' was Ercole II d'Este's motto: see J. Gelli, Divise - motti e imprese di famiglie e personaggi italiani (Milan, 1976), pp. 384 and 453-4.

76 ' $[\mathrm{C}]$ on questo mezzo io potesse far conoscere in parte à V. S. Illustrissima \& Reverend. la devotione \& la oßervanza, la quale già molti anni sono, ho per le sue rare qualità, nell'animo mio verso lei conceputo; dedicandole queste mie poche fatiche.'

77 Zarlino, Sopplimenti musicali (Venice, 1588), p. 288: '[L]a simiglianza ... tra l'Hidraulica \& l'Organo nostro, mosse l'Illustr. S. Suor Leonora d'Este, l'Anno 1571. nel mese di Novembre, à farmi richiedere da Francesco Viola gia mio singolare amico, Se cotale Organo era antico ò pur moderno, \& dov'ei prendesse il suo nome; alla quale havendo primo risposto, mosso da questa richiesta, deliberai di Scrivere i presenti Sopplementi; non però con quell'ordine c'hò tenuto, ma secondo che mi soccorrevano ò secondo'l tempo nelquale m'erano richieste le cose, à modo d'una Selva, nella quale siano piantati molti alberi à caso \& senz'ordine alcuno. Et questa fù la prima dimanda, ch'io scrivessi in questo proposito. Laonde la porrò seguentemente, per satisfare alla curiosità de molti, che desiderano sapere cotal cosa.' VIII, ch. 3 bears the title 'Che gli Antichi sonavano in Consonanza; \& se l'Organo nostro Istrumento sia antico ò moderno'. 
particular. For example, she has discovered a payment to the stationer Antonio Maria de Siviero for lining paper with staves ('carta rigata') so Jean Michel could copy various 'libri da canto' for Sister Leonora in 1532. ${ }^{78}$ Furthermore, 'Zoanne organista' received money in 1535 for repairing (possibly tuning) her organ, ${ }^{79}$ and the instrument maker Zoanmarco da Lugo for buying strings in order to make a clavichord for her. ${ }^{80}$ This evidence not only points to Leonora's knowledge of music, but also offers a plausible context for her contact with Zarlino and his statements in the Sopplimenti musicali.

Although Zarlino was never officially associated with the Este court, there is enough evidence to assume that he had good connections with several members of this family. Moreover, as we discover in the inventory of Zarlino's goods, drawn up shortly after his death in February 1590, he kept two gold medals from the Duke of Ferrara ('doi medaglie d'oro del duca di Ferrara') in his house. ${ }^{81}$ Needless to say, this is a clear sign of the special role the Este family in general and Duke Alfonso II in particular had played during Zarlino's life. These insights not only put into perspective the traditional view of Zarlino as being linked almost exclusively to

78 Archivio di Stato di Modena, Camera ducale estense, Guardaroba, registro n. 152, 15291534, c. 61 (20 June 1532): 'A maistro Antonio Maria de Siviero cartolaro per tanta carta rigata dacta a Zoan Michiele cantore per fare libri da canto per sore Leonora fiola del signor nostro in del Corpo de Cristo $£ 2.4 .0$ ' (private communication from Camilla Cavicchi, 14 and 17 October 2007). I am extremely grateful to Dr Cavicchi for allowing me to cite these archival documents. On the singer and copyist Jean Michel, see especially L. Lockwood, 'Jean Mouton and Jean Michel: New Evidence on French Music and Musicians in Italy, 1505-1520', fournal of the American Musicological Society, 32 (1979), pp. 191-246 and J. Rifkin, 'Jean Michel, Maistre Jhan and a Chorus of Beasts', in Tijdschrift van de Koninklijke Vereniging voor Nederlandse Muziekgeschiedenis, 52 (2002), pp. 67-102. On Sivieri, see A. Nuovo, Il commercio librario a Ferrara tra XV e XVI secolo: La bottega di Domenico Sivieri (Storia della tipografia e del commercio librario, 3; Florence, 1998).

79 Archivio di Stato di Modena, Camera ducale estense, Libri camerali diversi, Registro n. 335, 1535, c. XXXV (18 March 1535): 'Allo illustrissimo signor nostro al suo capitolo ducati dodeci d'oro in oro e per sua signoria a Zoanne organista contanti per sua mercede de havere cunzo l'organo de la reverenda sora Leonora del Corpo de Cristo per vigore de uno mandato ducale registrato nel registro de la ducale camera e appare mandato $\mathcal{f}^{40.4 .0}$ ' (private communication from Dr Cavicchi, 14 and 17 October 2007).

${ }^{80}$ Archivio di Stato di Modena, Camera ducale estense, Libri camerali diversi, Registro n. 300, 1525-1529, c. 23 (7 October 1525): 'Zoanmarco da Lugo per comprare corde per fornire uno clavicordo per la illustrissima donna Leonora in del Corpo di Cristo, figliola del signor nostro £0.15.0' (private communication from Dr Cavicchi, 14 October 2007).

81 Archivio di Stato di Venezia, Cancellaria inferiore, miscellanea notai diversi, b. 43, notaio G. N. Doglioni (8 February 1590). Quoted after I. Palumbo-Fossati, 'La casa veneziana di Gioseffo Zarlino nel testamento e nell'inventario dei beni del grande teorico musicale', Nuova Rivista Musicale Italiana, 20 (1986), pp. 633-49, at 641 and 649. 
Venice, but they also provide new information about the subtle strategies of Este patronage.

With the composition of Miserere mei Deus and Misereris omnium, Zarlino was able to pursue several goals. First of all, he paid double homage to the musical past by referring to a tradition that had started with Josquin's Miserere mei Deus and that was kept alive by the Infelix ego settings of Willaert, Rore and Vicentino. Secondly, by further exploring the compositional possibilities of a deceivingly simple motif, he could not only follow in their musical footsteps, but also continue the prestigious pattern of Este patronage. Finally, through the publication of his musical diptych in the Modulationes sex vocum of 1566, it becomes clear once more that 'Zarlino masterfully and meticulously manipulated his public image through the medium of print'. ${ }^{22}$ Around Miserere mei Deus and Misereris omnium, he wove a web of self-citation on several levels. Not only do both pieces refer to each other through their liturgical (Ash Wednesday), thematic (penitential tone) and musical correspondences (quotation of the Miserere motif, two-part canon on the same cantus firmus), but Zarlino also connects them twice in the revised edition of Le istitutioni harmoniche. Apart from their intrinsic qualities, Miserere mei Deus and Misereris omnium were part of Zarlino's 'hidden agenda', which consisted of strategically promoting his theoretical and musical achievements as the two inseparable pillars of his oeuvre. ${ }^{83}$

Ludwig-Maximilians-Universität München

${ }^{82}$ Judd, Reading Renaissance Music Theory, p. 184.

${ }^{83}$ See also his ideas about the 'musico perfetto' in Bk. I, ch. 11 of Le istitutioni harmoniche, as well as the following statement in Bk. III, ch. 65: 'Theory without practice, as I have said, is of small value, since music does not consist only of theory and is imperfect without practice. This is obvious enough. Yet some theorists, treating of certain musical matters without having good command of the actual practice, have spoken much nonsense and committed a thousand errors. On the other hand, some who have relied only on practice without knowing the reasons behind it have unwittingly perpetrated thousands upon thousands of idiocies in their compositions' (Et se la Speculativa senza la Prattica [come altre volte hò detto] val poco; atteso che la Musica non consiste solamente nella Speculativa; cosi questa senza la prima è veramente imperfetta. Et questo è manifesto: conciosia che havendo voluto alcuni Theorici trattare alcune cose della Musica; per non havere havuto buona cognitione della Prattica, hanno detto mille chiachiere, \& commesso mille errori. Simigliantemente alcuni, che si hanno voluto governare con la sola Prattica, senza conoscere alcuna ragione, hanno fatto nelle loro compositioni mille, \& mille pazzie, senza punto avedersene di cosa alcuna; p. 261). Translation quoted from Marco and Palisca, The Art of Counterpoint, pp. 226-7. 
